\title{
A global compilation of coccolithophore calcification rates
}

\author{
Chris J. Daniels ${ }^{1}$, Alex J. Poulton ${ }^{1,2}$, William M. Balch ${ }^{3}$, Emilio Marañón ${ }^{4}$, Tim Adey ${ }^{5}$, \\ Bruce C. Bowler ${ }^{3}$, Pedro Cermeño ${ }^{6}$, Anastasia Charalampopoulou ${ }^{5}$, David W. Crawford ${ }^{7,8}$, \\ Dave Drapeau ${ }^{3}$, Yuanyuan Feng ${ }^{9}$, Ana Fernández ${ }^{4}$, Emilio Fernández ${ }^{4}$, Glaucia M. Fragoso ${ }^{10}$, \\ Natalia González $^{11}$, Lisa M. Graziano ${ }^{3}$, Rachel Heslop ${ }^{5}$, Patrick M. Holligan ${ }^{5}$, Jason Hopkins ${ }^{3}$, \\ María Huete-Ortega ${ }^{12}$, David A. Hutchins ${ }^{13}$, Phoebe J. Lam ${ }^{14}$, Michael S. Lipsen ${ }^{15}$, \\ Daffne C. López-Sandoval ${ }^{16}$, Socratis Loucaides ${ }^{1,5}$, Adrian Marchetti ${ }^{17}$, Kyle M. J. Mayers ${ }^{5}$, \\ Andrew P. Rees ${ }^{18}$, Cristina Sobrino ${ }^{4}$, Eithne Tynan ${ }^{5}$, and Toby Tyrrell ${ }^{5}$ \\ ${ }^{1}$ National Oceanography Centre, Southampton, SO14 3ZH, UK \\ ${ }^{2}$ The Lyell Centre for Earth and Marine Sciences and Technology, \\ Heriot-Watt University, Edinburgh, EH14 4AS, UK \\ ${ }^{3}$ Bigelow Laboratory for Ocean Sciences, East Boothbay, ME 04544, Maine, USA \\ ${ }^{4}$ Departamento de Ecología y Biología Animal, Universidad de Vigo, 36310 Vigo, Spain \\ ${ }^{5}$ Ocean and Earth Science, National Oceanography Centre Southampton, \\ University of Southampton, Southampton, SO14 3ZH, UK \\ ${ }^{6}$ Instituto de Cièncias del Mar, CSIC, E08003 Barcelona, Spain \\ ${ }^{7}$ Climate Chemistry Laboratory, Institute of Ocean Sciences, \\ Fisheries and Oceans Canada, P.O. Box 6000, Sidney, BC V8L 4B2 Canada \\ ${ }^{8}$ Department of Biology, University of Victoria, Victoria, British Columbia V8W 2YA, Canada \\ ${ }^{9}$ Tianjin University of Science and Technology, Tianjin Shi, 300457, China \\ ${ }^{10}$ Trondhjem Biological Station, Department of Biology, Norwegian University \\ of Science and Technology, 7491 Trondheim, Norway \\ ${ }^{11}$ Biodiversity and Conservation Area, Universidad Rey Juan Carlos, 28933 Madrid, Spain \\ ${ }^{12}$ Department of Plant Sciences, University of Cambridge, Cambridge, CB2 3EA, UK \\ ${ }^{13}$ Department of Biological Sciences, University of Southern California, Los Angeles, CA 90089, USA \\ ${ }^{14}$ Department of Ocean Sciences, University of California, Santa Cruz, California, CA 95064, USA \\ ${ }^{15}$ Department of Earth, Ocean and Atmospheric Sciences, University of British Columbia, \\ Vancouver, British Columbia BC V6T 1Z4, Canada \\ ${ }^{16}$ Red Sea Research Center, King Abdullah University of Science \\ and Technology, Thuwal 23955-6900, Saudi Arabia \\ ${ }^{17}$ Department of Marine Sciences, University of North Carolina \\ at Chapel Hill, North Carolina, NC 27599, USA \\ ${ }^{18}$ Plymouth Marine Laboratory, Prospect Place, West Hoe, Plymouth, PL1 3DH, UK
}

Correspondence: Alex J. Poulton (a.poulton@hw.ac.uk)

Received: 13 April 2018 - Discussion started: 18 May 2018

Revised: 17 September 2018 - Accepted: 23 September 2018 - Published: 16 October 2018

Abstract. The biological production of calcium carbonate $\left(\mathrm{CaCO}_{3}\right)$, a process termed calcification, is a key term in the marine carbon cycle. A major planktonic group responsible for such pelagic $\mathrm{CaCO}_{3}$ production (CP) is the coccolithophores, single-celled haptophytes that inhabit the euphotic zone of the ocean. Satellitebased estimates of areal CP are limited to surface waters and open-ocean areas, with current algorithms utilising the unique optical properties of the cosmopolitan bloom-forming species Emiliania huxleyi, whereas little understanding of deep-water ecology, optical properties or environmental responses by species other than 
E. huxleyi is currently available to parameterise algorithms or models. To aid future areal estimations and validate future modelling efforts we have constructed a database of $2765 \mathrm{CP}$ measurements, the majority of which were measured using 12 to $24 \mathrm{~h}$ incorporation of radioactive carbon $\left({ }^{14} \mathrm{C}\right)$ into acid-labile inorganic carbon $\left(\mathrm{CaCO}_{3}\right)$. We present data collated from over 30 studies covering the period from 1991 to 2015, sampling the Atlantic, Pacific, Indian, Arctic and Southern oceans. Globally, CP in surface waters $(<20 \mathrm{~m})$ ranged from 0.01 to $8398 \mu \mathrm{mol} \mathrm{C} \mathrm{m} \mathrm{C}^{-3} \mathrm{~d}^{-1}$ (with a geometric mean of $16.1 \mu \mathrm{mol} \mathrm{C} \mathrm{m}^{-3} \mathrm{~d}^{-1}$ ). An integral value for the upper euphotic zone (herein surface to the depth of $1 \%$ surface irradiance) ranged from $<0.1$ to $6 \mathrm{mmol} \mathrm{C} \mathrm{m}^{-2} \mathrm{~d}^{-1}$ (geometric mean $1.19 \mathrm{mmol} \mathrm{m}^{-2} \mathrm{~d}^{-1}$ ). The full database is available for download from PANGAEA at https://doi.org/10.1594/PANGAEA.888182.

\section{Introduction}

The formation, export and burial of $\mathrm{CaCO}_{3}$ is an important component of the oceanic carbon cycle, with the combination of the first two providing a positive feedback on atmospheric $\mathrm{CO}_{2}$ (Archer, 1996; Sarmiento et al., 2002; Berelson et al., 2007). Around half of oceanic $\mathrm{CaCO}_{3}$ production occurs in shallow neritic environments, with the remainder occurring in the upper waters of the open ocean (Milliman, 1993). Export and deep-sea burial in the open ocean are both relatively well characterised in terms of global magnitude (Milliman, 1993; Berelson et al., 2007) and regional trends (e.g. Archer, 1996; Henson et al., 2012) and are often (simply) parameterised in global biogeochemical models (e.g. Gehlen et al., 2007; Yool et al., 2013) as a function of carbonate chemistry. The scale of biological formation of $\mathrm{CaCO}_{3}$ in the upper ocean, however, is poorly constrained, in terms of both its magnitude and biogeography (Berelson et al., 2007), due to knowledge gaps existing in the ecological and physiological understanding which is fundamental to allow accurate or reliable parameterisation at a global scale (Balch et al., 2007; Monteiro et al., 2016; Krumhardt et al., 2017; Hopkins and Balch, 2018).

Problems with forming such a global perspective on pelagic $\mathrm{CaCO}_{3}$ production partly arise due to the diversity of the different planktonic organisms involved (coccolithophores; foraminifera; pteropods; and, to a lesser extent some dinoflagellates, Meier et al., 2007, and cyanobacteria, Merz-Preiß, 2000), as well as our incomplete understanding of their ecology and physiology and a lack of in situ global measurements. Despite recent advances in understanding the biomass distribution of coccolithophores and foraminifera (O'Brien et al., 2013, 2016; Schiebel and Movellan, 2012), and how these may relate to carbonate chemistry (e.g. Bach et al., 2015; Evans et al., 2016; Krumhardt et al., 2017), we still have very little idea of the relative magnitude (or biogeography) of their respective rates in terms of production or export (e.g. Schiebel, 2002; Berelson et al., 2007).

A key misconception when considering oceanic $\mathrm{CaCO}_{3}$ production by coccolithophores is the enigmatic role of Emiliania huxleyi in satellite imagery of $\mathrm{CaCO}_{3}$ (or particulate inorganic carbon, PIC). The characteristic light-scattering properties of PIC particles and the size of E. huxleyi coccoliths (Balch et al., 1996), in addition to its ubiquitous distribution, tendency to shed excess coccoliths and propensity to form massive turbid blooms, has set the focus on this species in the development of algorithms for satellite ocean-colour remote sensing of PIC measurements (Balch et al., 2005; Balch, 2018). Several studies have used satellite images to examine trends in global PIC production, in terms of regional variability, areal magnitude (e.g. Balch et al., 2005, 2007; Freeman and Lovenduski, 2015; Hopkins and Balch, 2018) and coccolithophore ecology (e.g. Hopkins et al., 2015). However, these budgets are likely to be less accurate in terms of fully accounting for PIC contributions from the whole water column (but see Balch et al., 2018) or entire coccolithophore assemblage as considerable variability arises in coccolith-specific backscattering coefficients (Balch et al., 1999) due to a wide range of coccolith sizes, shapes, morphologies and $\mathrm{CaCO}_{3}$ contents (Young and Ziveri, 2000; Young et al., 2003). Relatively small differences in the $\mathrm{CaCO}_{3}$ content of the various E. huxleyi morphotypes (Young et al., 2003; Poulton et al., 2011; Charalampopoulou et al., 2016) can have significant impact in terms of satellite retrieval of PIC concentrations (Holligan et al., 2010; Balch, 2018) and $\mathrm{CaCO}_{3}$ formation at the scale of mesoscale blooms (Poulton et al., 2013). Moreover, recent studies have highlighted the potential for less abundant, yet more heavily calcified species other than E. huxleyi to dominate coccolithophore $\mathrm{CaCO}_{3}$ production (Daniels et al., 2014, 2016), and hence there is a need to better consider community-wide $\mathrm{CaCO}_{3}$ production. Satellites also detect relatively localised bloom events, whereas the non-bloom production in temperate waters may be relatively substantial (e.g. Poulton et al., 2010). Moreover, the areal extent of mid- to low-latitude waters confers them with a substantial global role in integrated $\mathrm{CaCO}_{3}$ budgets (e.g. Balch et al., 2005; Marañón et al., 2016).

Here we focus on the pelagic $\mathrm{CaCO}_{3}$ production (CP) from the global ocean, taking advantage of a recent increase in the oceanic measurement of calcification rates across diverse ocean environments. As almost all coccolithophore species, with a few notable exceptions (Young et al., 1999), produce the calcite isomorph of $\mathrm{CaCO}_{3}$, the terms $\mathrm{CaCO}_{3}$ 
production and calcite production may be considered interchangeable for coccolithophores. However, it also has to be noted that the methodology (see Sect. 2.1.2) to determine CP does not distinguish the actual form of $\mathrm{CaCO}_{3}$, whether it is calcite (coccolithophores, foraminifera, some dinoflagellates) or aragonite (foraminifera, pteropods, corals).

The ecology and physiology of coccolithophores has been reviewed numerous times (see Paasche, 2002; Zondervan, 2007; Boyd et al., 2010; Raven and Crawfurd, 2012; Monteiro et al., 2016; Taylor et al., 2016; Krumhardt et al., 2017; Balch, 2018). Recent advances also include a better understanding of coccolithophore calcification in the context of carbonate chemistry (Bach et al., 2015), energetic considerations (Monteiro et al., 2016) and phytoplankton succession (Hopkins et al., 2015).

Paasche $(1962,1963)$ first proposed direct measurements of coccolithophore production of $\mathrm{CaCO}_{3}$ by demonstrating that radioactive carbon-14 $\left({ }^{14} \mathrm{C}\right)$ could trace the production of both organic (via photosynthesis) and inorganic carbon (via calcification) by coccolithophores in the laboratory. The use of ${ }^{14} \mathrm{C}$ to measure photosynthesis dates back to Steeman Nielsen in the 1950s (see Barber and Hilting, 2002), with a key step being the acid treatment of filtered material (post-incubation) to remove any remaining ${ }^{14} \mathrm{C}$-labelled dissolved inorganic carbon $\left({ }^{14} \mathrm{C}\right.$-DIC) as ${ }^{14} \mathrm{CO}_{2}$ (e.g. Knap et al., 1996; Marra, 2002). However, if the filtered samples are rinsed (extensively) with unlabelled seawater to remove any unfixed ${ }^{14} \mathrm{C}$-DIC before acid exposure, then the ${ }^{14} \mathrm{CO}_{2}$ liberated upon acidification of the filters represents ${ }^{14} \mathrm{C}$-DIC fixed into $\mathrm{Ca}^{14} \mathrm{CO}_{3}$ (i.e. $\mathrm{CP}$ ).

Two techniques exist to utilise this production of ${ }^{14} \mathrm{CO}_{2}$ to measure calcification, and these have been used in numerous field studies (Table 1). The first requires filtering ${ }^{14} \mathrm{C}$-labelled samples post-incubation through two filters; one is then fumed with acid (e.g. hydrochloric acid) to remove the $\mathrm{Ca}^{14} \mathrm{CO}_{3}$ (and then termed particulate organic production), while the other is left un-fumed (termed total particulate production, TPP). Calcification (particulate inorganic production) then represents the difference between the particulate production of these two filters. The second method (the micro-diffusion technique, MDT) directly captures the ${ }^{14} \mathrm{CO}_{2}$ liberated from $\mathrm{Ca}^{14} \mathrm{CO}_{3}$, providing a direct measurement of calcification with a high degree of accuracy.

The objective of this study was to create a database compiling all the available in situ measurements of $\mathrm{CaCO}_{3}$ production in the ocean. By synthesising the numerous individual datasets into one database, we hope to provide a baseline for validation of model outputs and satellite algorithms. Two previous data syntheses (Balch et al., 2007; Poulton et al., 2007) were published around a decade ago, though the datasets included were smaller with some geographical biases (i.e. a large amount of (sub-)tropical data): the present dataset aims to synthesise all the available calcification rate data and will be updated as new data become available. Poulton et al. (2007) previously noted a significant geographical bias in the data collected, with most data originating from (sub-)tropical waters, whereas measurements are now available from more diverse regions, such as the Arctic (e.g. Charalampopoulou et al., 2011; Balch et al., 2014; Daniels et al., 2016) and Southern Ocean (e.g. Balch et al., 2016; Charalampopoulou et al., 2016).

\section{Data and methods}

The database is available from PANGAEA at doi:10.1594/ PANGAEA.888182 (Poulton et al., 2018).

\subsection{Database construction}

\subsubsection{Database summary}

Data were compiled from the available scientific literature, with permission to include each dataset acquired from the lead author and/or principal investigator where appropriate. Following the initial data collection, oceanographic cruises with unpublished data were identified, and the data owners and originators were contacted for permission and access to include those further datasets. The data consist of direct measurements of $\mathrm{CaCO}_{3}$ production $(\mathrm{CP})$ and primary production (PP); cell counts of coccolithophores (where available, not differentiated by species in this database); and ancillary data, including the collection date and year, latitude, longitude, sampling and light depth (when available), incubation length ( $\leq 12$ or $24 \mathrm{~h}$ ) and method of measuring CP (via difference or MDT). The quality-controlled (see Sect. 2.2) database consists of 2765 data points, with coccolithophore cell counts matched to 1301 data points.

\subsubsection{Calcium carbonate production and primary production}

$\mathrm{CaCO}_{3}$ production (CP) was mostly measured using ${ }^{14} \mathrm{C}$, with one study using ${ }^{45} \mathrm{Ca}$ as a tracer (Van der Wal et al., 1995) (Table 1). Water samples $(<0.5 \mathrm{~L})$ were collected via various methods (e.g. Go-Flo bottles, Niskin bottles with rosette samplers, uncontaminated surface seawater supply), spiked with various activities $(\sim 2$ to $100 \mu \mathrm{Ci}$ or $\sim 74$ to $3700 \mathrm{kBq}$ ) of ${ }^{14} \mathrm{C}$-labelled bicarbonate and incubated for 5 to $24 \mathrm{~h}$ under various light regimes (see original references in Table 1 for full methodological details). As CP is measured on small volumes $(<0.5 \mathrm{~L})$, with coccolithophore abundances ranging from 10 to 2000 cells $\mathrm{mL}^{-1}$, such measurements are likely to, but not exclusively, exclude CP from large $(63-200 \mu \mathrm{m})$ and rare calcifying organisms, such as foraminifera (typically $\leq 0.5 \mathrm{~L}^{-1}$; e.g. Schiebel and Movellan, 2012) or pteropods (typically $\leq 0.005 \mathrm{~L}^{-1}$; Burridge et al., 2017).

Two techniques were used with ${ }^{14} \mathrm{C}$ : the difference method and the MDT (Table 1). For measurements by difference, the incubations are terminated by filtering the sample onto two 


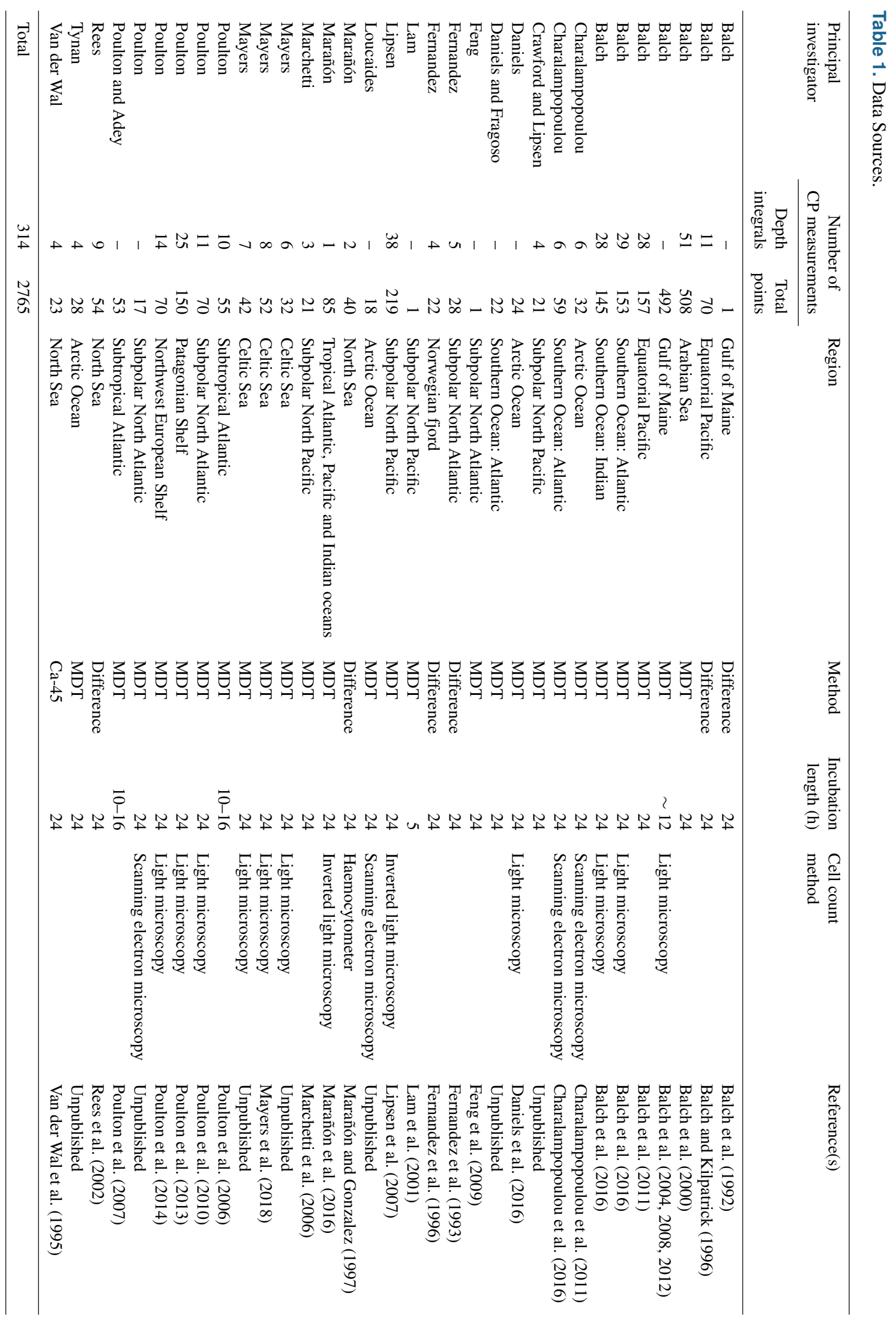


replicate filters. One filter is fumed with acid (most often hydrochloric acid) to remove the acid-labile inorganic carbon (i.e. $\mathrm{CaCO}_{3}$ ), leaving non-acid-labile particulate organic carbon, while the other is untreated. The radioactivity of the two filters is measured using liquid scintillation counting to determine the total carbon fixation (inorganic + organic carbon fixation, often termed total particulate production) on the untreated filter and the organic carbon fixation (often termed primary production) on the acid-fumed filter. $\mathrm{CaCO}_{3}$ production is then determined as the difference between these two measurements. This technique can provide accurate estimates of $\mathrm{CP}$ when rates are high (and ratios of $\mathrm{CP}$ to PP are near unity), such as in coccolithophore blooms (e.g. Fernandez et al., 1993) or laboratory cultures (e.g. Balch et al., 1992). However, the accuracy of this technique suffers significantly in oceanic samples where $\mathrm{CP}$ can be much smaller than PP (less than a tenth of PP; Poulton et al., 2007), such that $\mathrm{CP}$ is calculated as the difference between two large numbers with potentially large errors (see Appendix A).

The MDT overcomes the limitations of the difference method, as it is able to measure directly both $\mathrm{CP}$ and PP from the same water sample, using only one filter (Balch et al., 2000; Paasche and Brubak, 1994). Following the incubation of seawater spiked with ${ }^{14} \mathrm{C}$-bicarbonate, the sample is filtered and extensively rinsed with non-labelled pre-filtered seawater, and the filter is placed into a glass vial. A glass fibre filter (e.g. Whatman GF/A), presoaked with an alkaline solution (Balch et al., 2000) or $\beta$-phenylethylamine (Poulton et al., 2006; Balch et al., 2011), is suspended within the vial to act as a $\mathrm{CO}_{2}$ trap. The sample filter is then acidified (e.g. $1 \%$ phosphoric acid; see Balch et al., 2000), liberating the acid-labile inorganic carbon $\left(\mathrm{CaCO}_{3}\right)$ as $\mathrm{CO}_{2}$. The resultant ${ }^{14} \mathrm{CO}_{2}$ is captured on the glass fibre filter over time $(>12 \mathrm{~h})$, which is then moved to a fresh vial from which CP can be measured directly. Measuring CP and PP from the same filter allows the MDT to reduce experiment error, resulting in more precise, reliable and accurate measurements of CP (Marañón and González, 1997; Balch et al., 2000, 2007). As a measure of abiotic isotope labelling of material, a formalin-killed blank incubation is run in parallel to the light samples and later subtracted (Balch et al., 2000).

An alternative method for measuring $\mathrm{CP}$ is through using ${ }^{45} \mathrm{Ca}$ as the tracer rather than ${ }^{14} \mathrm{C}$ (Van der Wal et al., 1995). Seawater is incubated with ${ }^{45} \mathrm{CaCl}$ and subsequently filtered. The advantage of this method is that it does not require the separation of inorganic and organic uptake, as required for either ${ }^{14} \mathrm{C}$ technique. However, ${ }^{45} \mathrm{Ca}$ forms strong ionic bonds, such that unincorporated ${ }^{45} \mathrm{Ca}$ is not easily removed by rinsing and blanks are often large (Balch et al., 2007; Van der Wal et al., 1995).

With the ability to measure low rates of CP, the MDT is the currently preferred method for measuring $\mathrm{CP}$ in the ocean, compared to both the difference method and ${ }^{45} \mathrm{Ca}$. This is reflected in the database, where $2527(91.4 \%)$ of the data points were measured using the MDT, $215(7.8 \%)$ using the difference technique and $23(0.8 \%)$ using ${ }^{45} \mathrm{Ca}$. For a comparison of the performance of the MDT and the difference technique on oceanic coccolithophore communities see Appendix A.

The majority of the data in the current database come from $24 \mathrm{~h}$ incubations, which capture a complete daily cycle of growth and account for any CP (or loss of fixed carbon via mortality) occurring at night (Poulton et al., 2007, 2010). However, several earlier studies used shorter incubation lengths and are highlighted in Table 1. The measurements collected by Poulton et al. $(2006,2007)$ were only incubated over the local daylight period (10-16h), and it was assumed that negligible $\mathrm{CP}$ occurred at night (e.g. Linschooten et al., 1991; but see Paasche, 1966; Balch et al., 1992). Samples collected in the Gulf of Maine (Balch et al., 2008) were brought back to the laboratory to measure photosynthesis and CP in half-day, CalCOFI-style (California Cooperative Oceanic Fisheries Investigations) incubations (see Mantyla et al., 1995). The half-day incubations minimised bottle effects (Balch et al., 2008), ran from local apparent midnight to midday, and were converted to daily rates of $\mathrm{CP}$ using ratios of 12 and $24 \mathrm{~h}$ incubations. Finally, Lam et al. (2001) incubated for $5 \mathrm{~h}$ around midday and calculated an hourly rate of CP. In this database, this hourly rate has been scaled up by the calculated day length based on latitude, longitude and seasonal timing of the study (see Kirk, 1994), assuming that no dark calcification occurred. It should be noted, however, that dark calcification has been observed in several laboratory cultures (Paasche, 1966; Linschooten et al., 1991; Balch et al., 1992) and longer incubations may be necessary. When appropriate, $\mathrm{CP}$ and PP data were standardised into units of $\mathrm{mmol} \mathrm{C} \mathrm{m}^{-3} \mathrm{~d}^{-1}$.

\subsubsection{Cell counts}

When available, cell counts for coccolithophores (Table 1) were generally performed using either polarised light microscopy (Balch et al., 2004, 2008, 2012, 2018; Balch et al., unpublished; Daniels et al., 2016; Mayers et al., 2018; Mayers et al., unpublished; Poulton et al., 2010, 2013, 2014; Poulton et al., unpublished) or scanning electron microscopy (Charalampopoulou et al., 2011, 2016; Loucaides et al., unpublished; Poulton et al., unpublished). Other methods for cell counting in the database include inverted light microscopy of formalin-preserved samples (Lipsen et al., 2007; Marañón et al., 2016) and use of a haemocytometer (Marañón and González, 1997).

With the exception of Marañón and González (1997), who report only the concentration of E. huxleyi, cell counts correspond to the total concentration of coccolithophores in each water sample. In 556 of these samples, both the total coccolithophore abundance and the E. huxleyi abundance are reported (Charalampopoulou et al., 2011, 2016; Daniels et al., 2016; Lipsen et al., 2007; Loucaides et al., unpublished; Mayers et al., 2018; Poulton et al., 2010, 2013; Poulton et 
al., unpublished). In all cases, the counts are reported in cells $\mathrm{mL}^{-1}$.

\subsubsection{Optical depths, depth integration and surface data}

There are 314 vertical profiles of $\mathrm{CP}$ within the database presented. From these profiles, depth-integrated values were calculated to represent euphotic zone integrated $\mathrm{CP}$ in which the euphotic zone is taken as either $1 \%$ (e.g. Poulton et al., 2006) or $0.1 \%$ (e.g. Balch et al., 2011) of incident irradiance in the different studies. Herein, it is assumed that CP only occurs within the euphotic zone and, therefore, euphotic zone integrated $\mathrm{CP}$ represents total water column $\mathrm{CP}$ by coccolithophores. Though coccolithophores may occur considerably deeper than the $1 \%$ irradiance depth (see e.g. Poulton et al., 2017), integration to the base of the euphotic zone allows comparison with other water-column processes frequently integrated to this depth (e.g. primary production, new production).

The light levels of the sampling depths, as a percentage of incident PAR, were provided either by the data originators or taken from the corresponding literature. Light depths were then converted to an equivalent optical depth by taking the negative natural logarithm approach where the $1 \%$ incident irradiance depth has an optical depth of 4.6 (see Kirk, 1994). Optical depth represents the path length of light through a medium and is the natural logarithm of the ratio of surface irradiance to irradiance at a specific depth, being proportional to the amount of light attenuation in the water column. Consideration of optical depth rather than absolute depth accounts for geographical patterns in the light field, recognising light as an important driver of CP. For example, $1 \%$ of surface irradiance (optical depth of 4.6 as natural log of 0.01 ) may reach $30 \mathrm{~m}$ in temperate waters with high attenuation, whereas it may reach $90 \mathrm{~m}$ in subtropical waters with low attenuation. If incidental irradiance was the same at both sites then both depths would receive the same light intensity independent of the difference in depth. The profiles were integrated by linearly interpolating using the sampling depths. There are 314 unique sampling stations with enough vertical resolution $(n \geq 4)$ to calculate euphotic zone integrals for $\mathrm{CP}$ (and PP) within the database.

However, a number of datasets included only upper-ocean sampling and a subset of surface of data was created by extracting data collected from less than $20 \mathrm{~m}$. In cases where multiple measurements were collected in this shallow window, only the data collected from the uppermost depth were extracted for the surface data comparison.

\subsection{Log-normal distribution and quality control}

Rates of $\mathrm{CP}$ and the abundance of coccolithophores in the ocean can range from zero when coccolithophores are either completely absent (e.g. in high-latitude polar waters) or below the limit of detection, up to extremely high values that may occur, for example, in a coccolithophore bloom. Consequently, both the CP rates and cell abundances can vary over many orders of magnitude, exhibiting a log-normal distribution (Fig. 4a) when excluding zero-value data. This distribution is typical of many biological processes (Limpert et al., 2001). For log-normally distributed data the geometric mean, rather than arithmetic mean, best characterises the data and hence we report only the geometric means from the database.

We quality-controlled the datasets by first removing all negative CP values. Negative values can occur in the difference method as CP is significantly smaller than PP and when the variability (replication) in PP between filters can be greater than the $\mathrm{CP}$ signal (see Appendix A). A negative rate can also be obtained using the MDT if the formalin-killed blank is greater than the measured rates, as may occur at low light levels at the base of the euphotic zone (e.g. Poulton et al., 2010) or in water samples with low rates of CP. A negative rate of $\mathrm{CP}$ cannot actually occur using the (single point) radioisotope tracer technique and, therefore, these rates were eliminated from the database. The decision was also made to remove all zero-value data points of $\mathrm{CP}$ and cell counts. In general, the methods used to measure $\mathrm{CP}$ and cell abundances are not sensitive enough to distinguish between true zero values and those below their limit of detection. Furthermore, the limit of detection will vary between users and specific details of their methods (e.g. volume used, spike activity added), and hence it is more consistent to remove all zero values from the database rather than set an arbitrary limit of detection for the whole database.

\section{Results and discussion}

\subsection{Data distribution}

Figure 1 shows the spatial distribution of the database of CP. The Atlantic Ocean has the best data coverage, particularly in the high latitudes of the North Atlantic. Coverage of the Southern Ocean is constrained to the Atlantic and Indian sectors. The Pacific Ocean is poorly represented with no coverage in the western Pacific. Although there is a large number of data in the Indian Ocean, it is restricted to the Arabian Sea (Balch et al., 2000). The most heavily sampled region is the Gulf of Maine (Table 1) (Balch et al., 2008, 2012).

There are significant gaps in the spatial distribution of the dataset, with a particular bias towards the Atlantic Ocean. However, the spatial coverage has greatly increased since 2006 (see Balch et al., 2007; Poulton et al., 2007), particularly in the high latitudes. Figure 2 shows the temporal and seasonal distribution of the data. The increase in spatial coverage is partly attributable to the general increase in data collection, with $44 \%$ of the data collected since 2006 . However, the seasonal distributions demonstrate bias towards the summer months of the Northern (June-August) and Southern (December-February) hemispheres (Fig. 2b and c). 

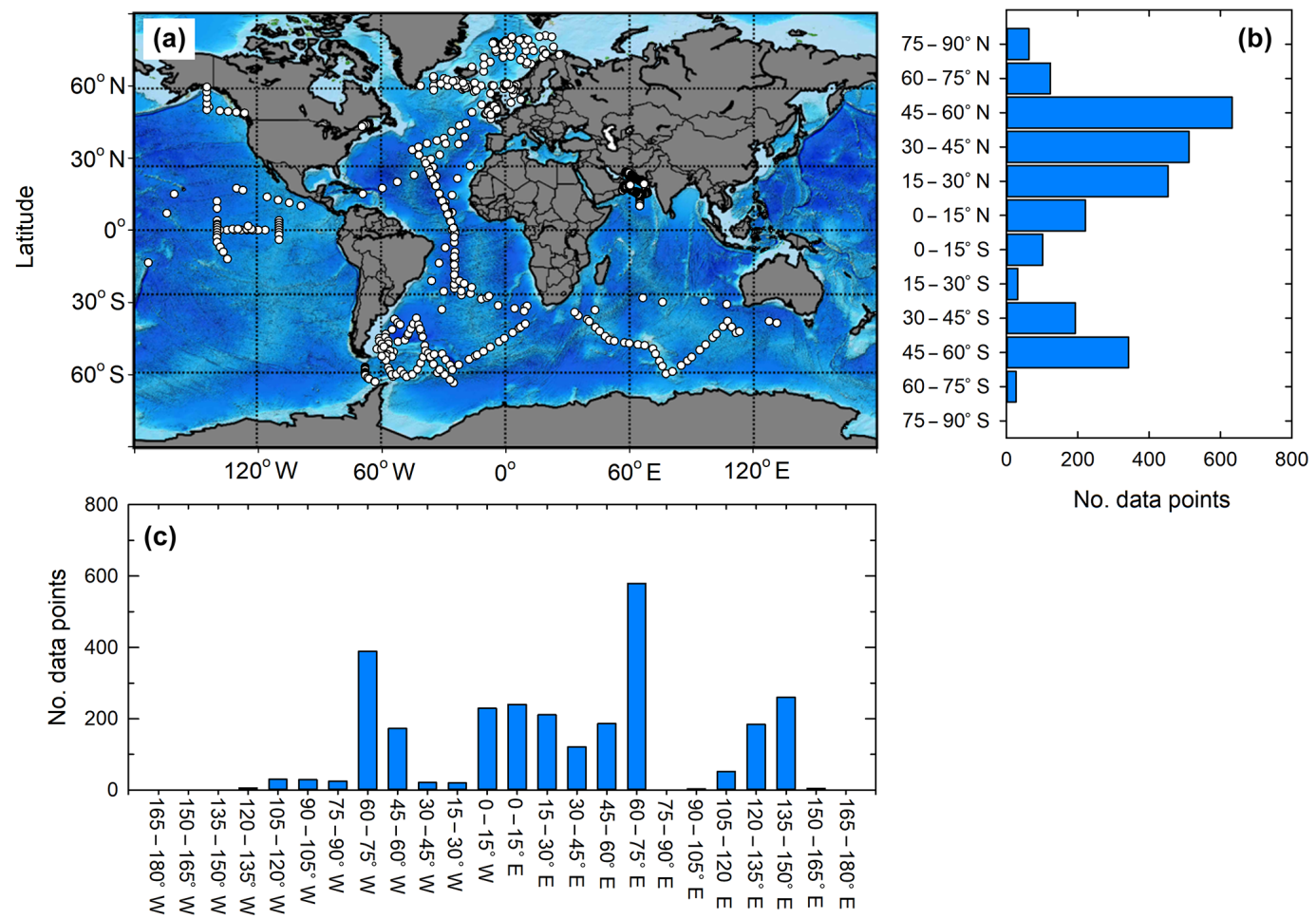

Figure 1. Global map of $\mathrm{CaCO}_{3}$ production data (a) and the frequency of data by latitude (b) and longitude (c). Global map in (a) superimposed on ocean bathymetry.

Figure 3 shows the vertical distribution of the database, in terms of depth and optical depth. Most data were collected from relatively shallow waters: $60 \%$ of samples were collected from less than $20 \mathrm{~m}$ and $41 \%$ at more than $50 \%$ of surface irradiance (optical depths $<0.7$ ).

\subsection{Magnitude of $\mathrm{CaCO}_{3}$ production rates}

The entire dataset of $\mathrm{CP}$ is well approximated by a lognormal distribution (Fig. 4a), with a geometric mean of $16.1 \mu \mathrm{mol} \mathrm{C} \mathrm{m} \mathrm{m}^{-3} \mathrm{~d}^{-1}$. The total range in $\mathrm{CP}$ is from 0.01 to $8398 \mu \mathrm{mol} \mathrm{C} \mathrm{m} \mathrm{m}^{-3} \mathrm{~d}^{-1}$, which has greatly expanded compared to Poulton et al. (2007). The highest measured CP rate occurred in the Gulf of Maine in July 2002 (Balch et al., 2012). Rates of $\mathrm{CP}$ in excess of $5000 \mu \mathrm{mol} \mathrm{C} \mathrm{m}{ }^{-3} \mathrm{~d}^{-1}$ were measured twice in a coccolithophore bloom in the Celtic Sea in April 2015 (Mayers et al., 2018). In total, there are 23 occurrences of CP rates over $1000 \mu \mathrm{mol} \mathrm{m}{ }^{-3} \mathrm{~d}^{-1}$, which is very likely indicative of coccolithophore blooms (Poulton et al., 2007, 2013).

\subsubsection{Surface $\mathrm{CaCO}_{3}$ production}

The surface CP data are also approximated by a log-normal distribution (Fig. 4b), with a slightly higher geometric mean $\left(20.3 \mu \mathrm{mol} \mathrm{C} \mathrm{m}^{-3} \mathrm{~d}^{-1}\right)$ than the complete dataset. Surface CP spans the entire range in CP $\left(0.01-8398 \mu \mathrm{mol} \mathrm{C} \mathrm{m}^{-3} \mathrm{~d}^{-1}\right)$, and is highly variable in the ocean (Fig. 5a). Some of this variability arises due to a lack of temporal resolution in Fig. 5, where 25 years of measurements are plotted alongside one another, with a recognisable seasonal bias towards summer in both hemispheres (Sect. 3.1). In general, surface $\mathrm{CP}$ is higher in the high-latitude North Atlantic (Fernandez et al., 1993; Poulton et al., 2010; Daniels et al., 2016), the Patagonian Shelf region of the South Atlantic (Poulton et al., 2013), the North Pacific (Lipsen et al., 2007) and in the Arabian Sea (Balch et al., 2000). Some of the lowest rates of $\mathrm{CP}$ are observed in the Southern Ocean (Charalampopoulou et al., 2016), although there is no clear pattern in the global distribution. The higher CP rates tend to be in well-sampled regions as studies have targeted areas known or predicted to be areas of significant coccolithophore abundances. This geographical (and seasonal) sampling bias may have resulted in an inflated global mean value of CP as there are only a few data points from regions where coccolithophores are thought to be rare (e.g. the subtropical Pacific and high-latitude polar seas).

\subsubsection{Integrated $\mathrm{CaCO}_{3}$ production}

Integrated $\mathrm{CP}$ is also log-normally distributed, with a geometric mean of $1.19 \mathrm{mmol} \mathrm{C} \mathrm{m}^{-2} \mathrm{~d}^{-1}$ and a range of $<0.01$ to $6 \mathrm{mmol} \mathrm{C} \mathrm{m}^{-2} \mathrm{~d}^{-1}$. As there are significantly fewer vertical profiles of $\mathrm{CP}$ (314) than surface measurements of $\mathrm{CP}$ 

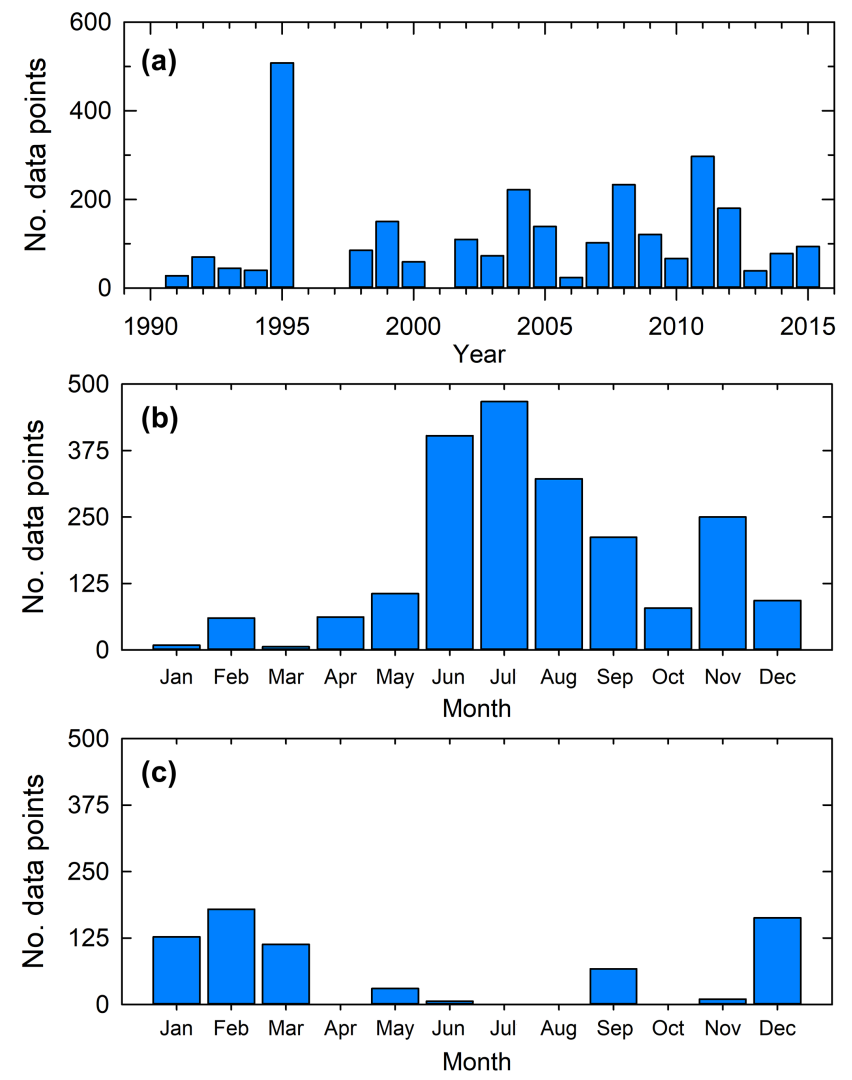

Figure 2. Frequency of $\mathrm{CaCO}_{3}$ production data by (a) year of measurement, (b) month of measurement in the Northern Hemisphere and (c) month of measurement in the Southern Hemisphere.

(1103), the spatial coverage of integrated CP is much sparser (Fig. 5b), particularly in the high-latitude North Atlantic. The pattern of integrated CP is slightly different to that of surface CP. Although integrated CP is high on the Patagonian Shelf, in the Arabian Sea and in the subpolar North Atlantic, it is also high in the equatorial Pacific. This partly reflects the deeper euphotic zones $(>60 \mathrm{~m})$ in the equatorial Pacific compared to the subpolar regions $(<50 \mathrm{~m})$ (see Landry et al., 2011). The vertical distribution of CP against optical depth is shown in Fig. 4c. The lack of a relationship between CP and optical depth for the entire dataset is partly due to the fact that the global variation in $\mathrm{CP}$ for any optical depth is greater than the vertical pattern in CP.

There is a strong positive correlation between surface CP and integrated CP (Pearson's product-moment correlation, $r=0.83, p<0.001, n=314$ ), when the logarithms of both are taken (Fig. 6). While a strong correlation between surface PP and integrated PP has been previously observed (e.g. Poulton et al., 2007) and is observed here (Fig. 7a), the relationship observed for CP by Poulton et al. (2007) was statistically weaker $(r=0.47, p<0.001, n=68)$. This difference may relate to the greater degree of temperate data in the larger database, where light will be a strong driver of deep
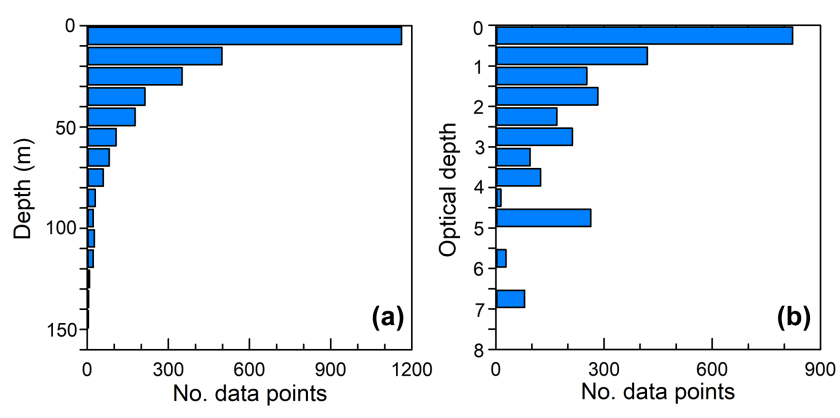

Figure 3. Frequency of $\mathrm{CaCO}_{3}$ production data by (a) sampling depth and (b) optical depth. Depths relate to depth of sample collection, not incubation depth.

$\mathrm{CP}$ within the mixed layer. In contrast, the previous database had a greater degree of tropical data, where deep thermocline CP may be strongly light-limited and/or dependent on nonautotrophic nutrition (Poulton et al., 2017).

\section{3 $\mathrm{CaCO}_{3}$ production versus primary production}

The ratio of CP to PP is highly variable in the database (Fig. 7a), with a log-normal distribution (Fig. 7b). The average (geometric mean) ratio of $\mathrm{CP}: \mathrm{PP}$ for the total database is 0.02 , though it has a range from as low as below 0.0001 to as high as over 5 . This distribution is highly similar to that observed by Poulton et al. (2007), though there is a much greater degree of variability within the expanded dataset (and potential issues with the more extreme values).

Broadly similar trends are observed when considering both surface CP and PP (Fig. 7c) and integrated CP and PP (Fig. 7e), with average CP : PP around 0.01 and 0.03 , respectively. As the average CP : PP ratio is lower in surface waters than in the total dataset, there may be a decoupling of PP and CP with depth and a greater light dependency for photosynthesis than calcification (see Balch and Kilpatrick, 1996; Balch et al., 2000, 2011; Poulton et al., 2007, 2010). The effect of optical depth on the ratio of CP to PP is shown in Fig. 7d. No general trend is identifiable, with data from deeper optical depths having similar CP : PP ratios to surface values. CP at depths below the light levels for photosynthetic growth may also relate to non-autotrophic nutritional strategies by deep-dwelling coccolithophore species (e.g. Poulton et al., 2017). No clear relationship is found between latitude and CP : PP (Fig. 7f).

The log-normal relationship between $\mathrm{CP}$ and $\mathrm{PP}$ can be potentially useful in a practical sense. Oceanic rates of PP are much more widely measured in field programmes, and therefore PP is better constrained than CP. By using the lognormal relationship between $\mathrm{CP}$ and PP identified in the global database we may be able to gain greater insights into spatial and temporal patterns, as well as the extent of CP. For example, global marine PP is estimated to be $\sim 50 \mathrm{Gt} \mathrm{C} \mathrm{yr}^{-1}$ (Field et al., 1998) while global CP by coccolithophores 

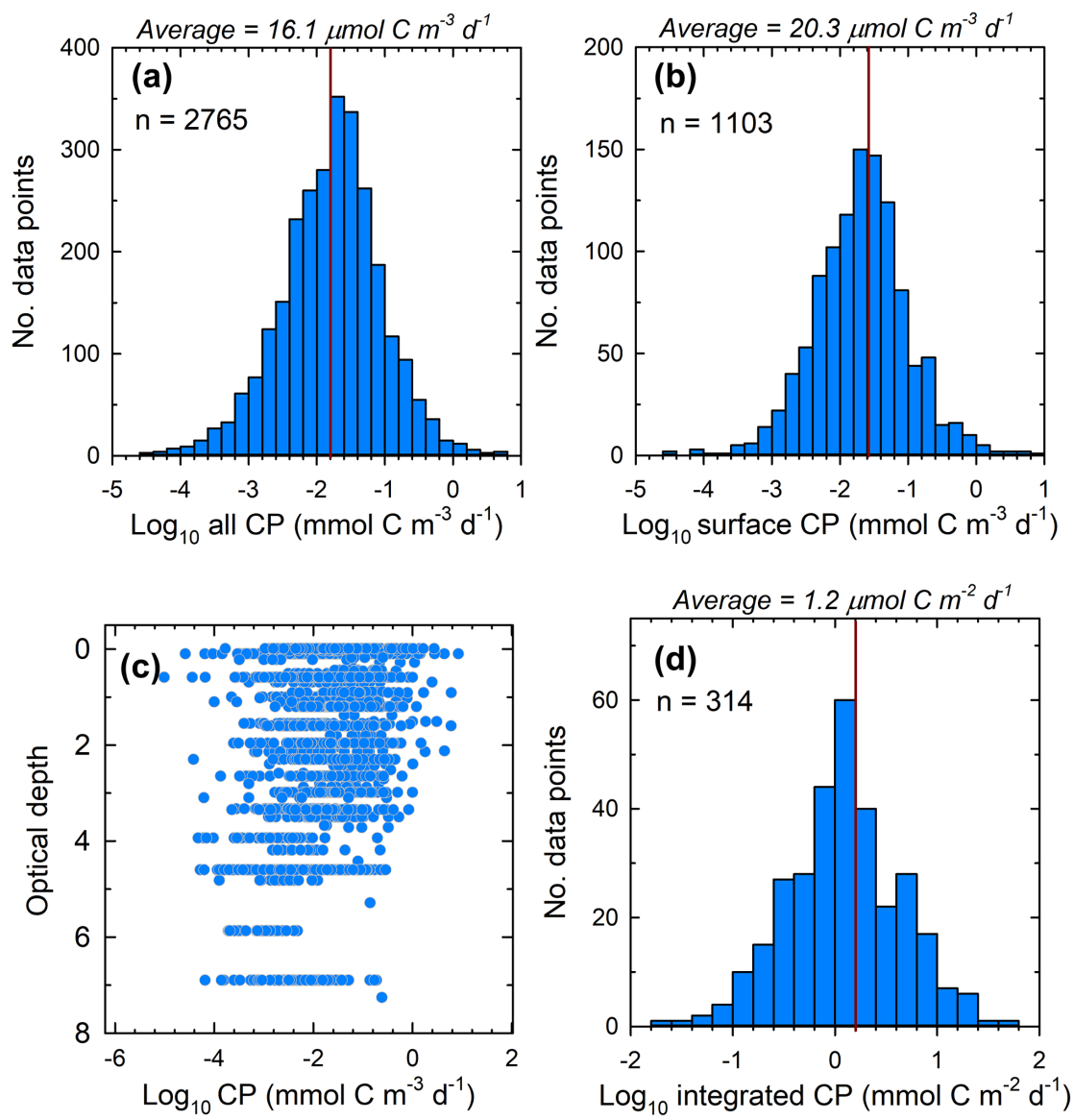

Figure 4. Characteristics of the $\mathrm{CaCO}_{3}$ production (CP) database: (a) measurement frequency versus all log-normalised $\mathrm{CP}$ data, (b) measurement frequency for log-normalised surface CP data only, (c) all log-normalised CP data versus optical depth and (d) measurement frequency for log-normalised euphotic zone integrated CP. Panels (a), (b) and (d) have geometric means presented.

is poorly constrained, with estimates ranging from 0.4 to 1.6 $\mathrm{Gt} \mathrm{C} \mathrm{yr}^{-1}$ (Balch et al., 2007; Berelson et al., 2007; Smith and Mackenzie, 2016). A first-order approximation of global $\mathrm{CP}$, using the average $\mathrm{CP}: \mathrm{PP}$ of 0.02 from the database, gives an estimate of $\sim 1 \mathrm{GtC} \mathrm{yr}^{-1}$. This value is only slightly lower than a recent estimate, based on coccolithophore ecophysiology, of $1.42 \mathrm{Gt} \mathrm{C} \mathrm{yr}^{-1}$ by Hopkins and Balch (2018). Clearly, more sophisticated methods can also be used in the future with the global CP database to better approximate regional and global estimates of CP.

\subsection{Cell-normalised calcification}

A key consideration in measurements of oceanic biogeochemical rates is the accuracy and representativeness of the resulting values. For PP (and photosynthesis), normalising rates to concentrations of chlorophyll $a$ (or phytoplankton carbon) gives information about the variability in production per unit biomass, where a solid understanding of photophysiology (e.g. Behrenfeld and Falkowski, 1997; Falkowski and Raven, 1997) helps to identify physiologically unrealis- tic rates. In the case of $\mathrm{CP}$, normalising to chlorophyll $a$ or particulate inorganic carbon can be considered inappropriate, as neither of them fully represent living coccolithophore biomass (Poulton et al., 2007).

We suggest that a more physiologically sound approach is to normalise $\mathrm{CP}$ to coccolithophore cell abundance (Poulton et al., 2010; Fig. 8), which provides a measure of calcification per unit biomass (cell-CP) comparable (in basic terms) to chlorophyll-normalised photosynthetic rates. Figure 8 shows the variability in cell-CP when normalising CP to total coccolithophore abundance using the matched values available in the database.

Within natural coccolithophore communities, CP is dependent on cell abundance, species composition and the rate of calcification per cell (Poulton et al., 2010; Daniels et al., 2014). Using cell-CP to examine coccolithophore dynamics is particularly appropriate when applied to communities dominated by a few species due to the sensitivity of cell$\mathrm{CP}$ to cellular $\mathrm{CaCO}_{3}$ content and hence species composition (Poulton et al., 2010; Charalampopoulou et al., 2011). More recently it has also been modified to account for variability 

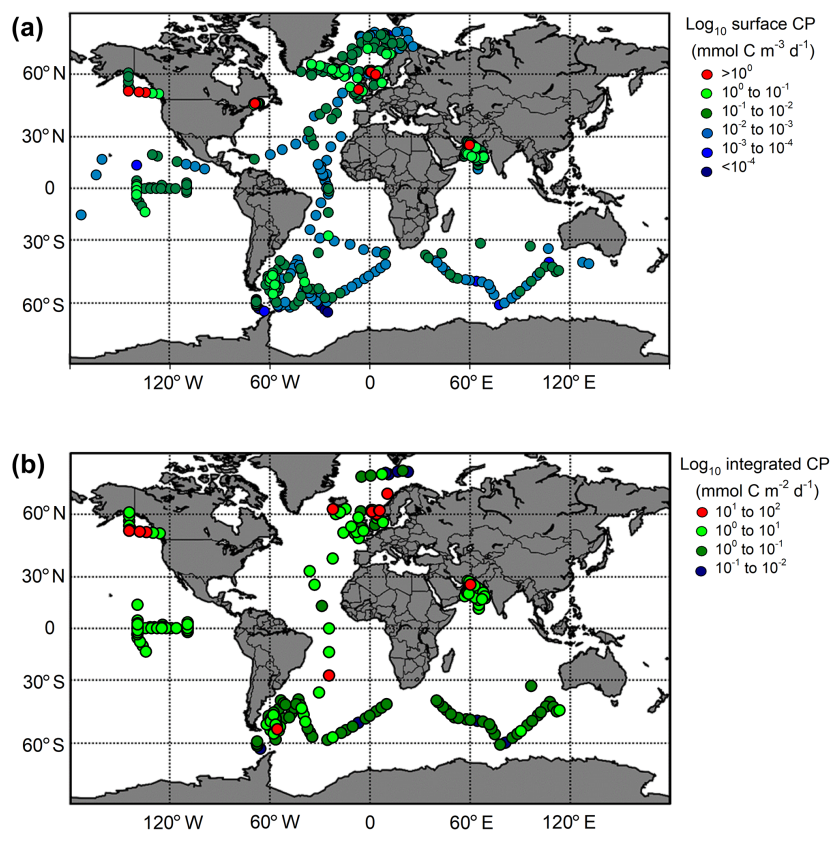

Figure 5. Global maps of (a) log-normalised surface $\mathrm{CaCO}_{3}$ production (CP) and (b) euphotic zone log-normalised integrated CP. Global maps superimposed on ocean bathymetry as in Fig. 1a. Note that global maps represent all measurements and are not temporally resolved.

in growth rates and species composition, allowing speciesspecific contributions to community $\mathrm{CP}$ to be constrained (Daniels et al., 2016).

The values of cell-CP in Fig. 8 range from < 0.001 to $46.4 \mathrm{pmolC}^{-1} \mathrm{Cl}^{-1} \mathrm{~d}^{-1}$, with a geometric mean of $0.42 \mathrm{pmolC} \mathrm{cell}^{-1} \mathrm{~d}^{-1} \quad(n=1272)$. The cell-CP of $E$. huxleyi-dominated natural communities is known to be variable, with average reported field values ranging from 0.16 to $0.65 \mathrm{pmolC}^{\mathrm{C} \text { cell }}{ }^{-1} \mathrm{~d}^{-1}$ across non-bloom communities in the North Atlantic and Southern Ocean, as well as bloom communities on the Patagonian Shelf (Poulton et al., 2010, 2013; Charalampopoulou et al., 2016). A cell-CP of $0.023 \mathrm{pmol} \mathrm{C}$ cell $^{-1} \mathrm{~d}^{-1}$, equivalent to an $E$. huxleyi coccolith production rate of $\sim 1 \mathrm{~d}^{-1}$ (Young and Ziveri, 2000; Poulton et al., 2010), can be considered close to a theoretical minimum cell-CP for E. huxleyi. Thus, samples in Fig. 8 with a cell-CP lower than this value could be dominated by slowgrowing $\left(<0.1 \mathrm{~d}^{-1}\right)$ low-calcite morphotypes of $E$. huxleyi (see Müller et al., 2015) or coccolithophore species with much lower cellular $\mathrm{CaCO}_{3}$ contents than E. huxleyi (e.g. Calciopappus caudatus; Daniels et al., 2016; Mayers et al., 2018). Conversely, those samples with a cell-CP significantly greater than $1 \mathrm{pmolC}$ cell ${ }^{-1} \mathrm{~d}^{-1}$ are likely to be dominated by coccolithophore species with greater cellular contents than E. huxleyi. Cell-CP for heavily calcified coccolithophore species such as Coccolithus pelagicus may reach as high as $\sim 8.3$ pmol cell ${ }^{-1} \mathrm{~d}^{-1}$ or $\sim 23.2$ pmol C cell ${ }^{-1} \mathrm{~d}^{-1}$ for $C$.

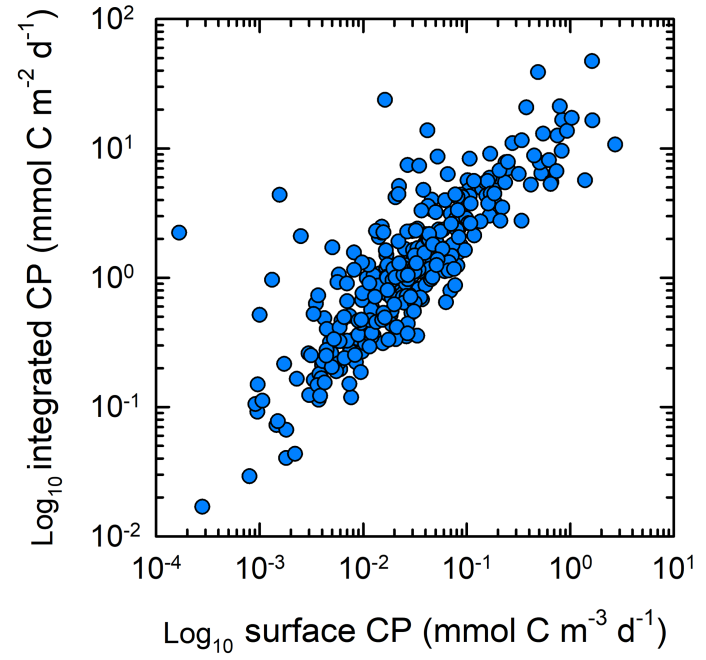

Figure 6. Scatterplot of log-normalised surface $(<20 \mathrm{~m}) \mathrm{CaCO}_{3}$ production $(\mathrm{CP})$ and euphotic zone log-normalised integrated $\mathrm{CP}$. The relationship between the two is statistically significant (Pearson's product-moment correlation, $r=0.83, p<0.001, n=314$ ).

braarudii (depending on the cell $\mathrm{CaCO}_{3}$ content and growth rate; Daniels et al., 2014). A theoretical maximum could therefore be considered as $\sim 40 \mathrm{pmol} \mathrm{C}$ cell $^{-1} \mathrm{~d}^{-1}$, based, for example, on a maximum growth rate of $0.6 \mathrm{~d}^{-1}$ for the heaviest extant coccolithophore species (Scyphosphaera apsteinii; Young and Ziveri, 2000) with $\sim 10$ to 12 coccoliths per coccosphere (Young et al., 2003) and a cell $\mathrm{CaCO}_{3}$ of $\sim 54$ to $65 \mathrm{pmol} \mathrm{C}$ cell $^{-1}$.

The values of cell-CP in the $\mathrm{CP}$ database (Fig. 8) are mostly within these theoretical limits, indicating that they can be viewed as realistic in the context of physiological limitations (growth and coccolith production rates) and extant species composition (cell and coccolith calcite quotas). Hence, cell-CP provides a useful benchmark for examining the physiological and growth dynamics of coccolithophore communities (e.g. Poulton et al., 2010, 2013; Charalampopoulou et al., 2016; Daniels et al., 2016; Mayers et al., 2018), as well as acting as a reality check for oceanic measurements of $\mathrm{CP}$. The relative species composition of mixed communities also has to be considered when examining trends in cell-CP (and total $\mathrm{CP}$ ), which fittingly links together the biogeochemically important role of coccolithophores in $\mathrm{CP}$ with their diversity in form, function and ecophysiology.

\section{Data availability}

The dataset is archived on the data repository PANGEA (https://www.pangaea.de/) under https://doi.org/10.1594/PANGAEA.888182 (Poulton et al., 2018). 

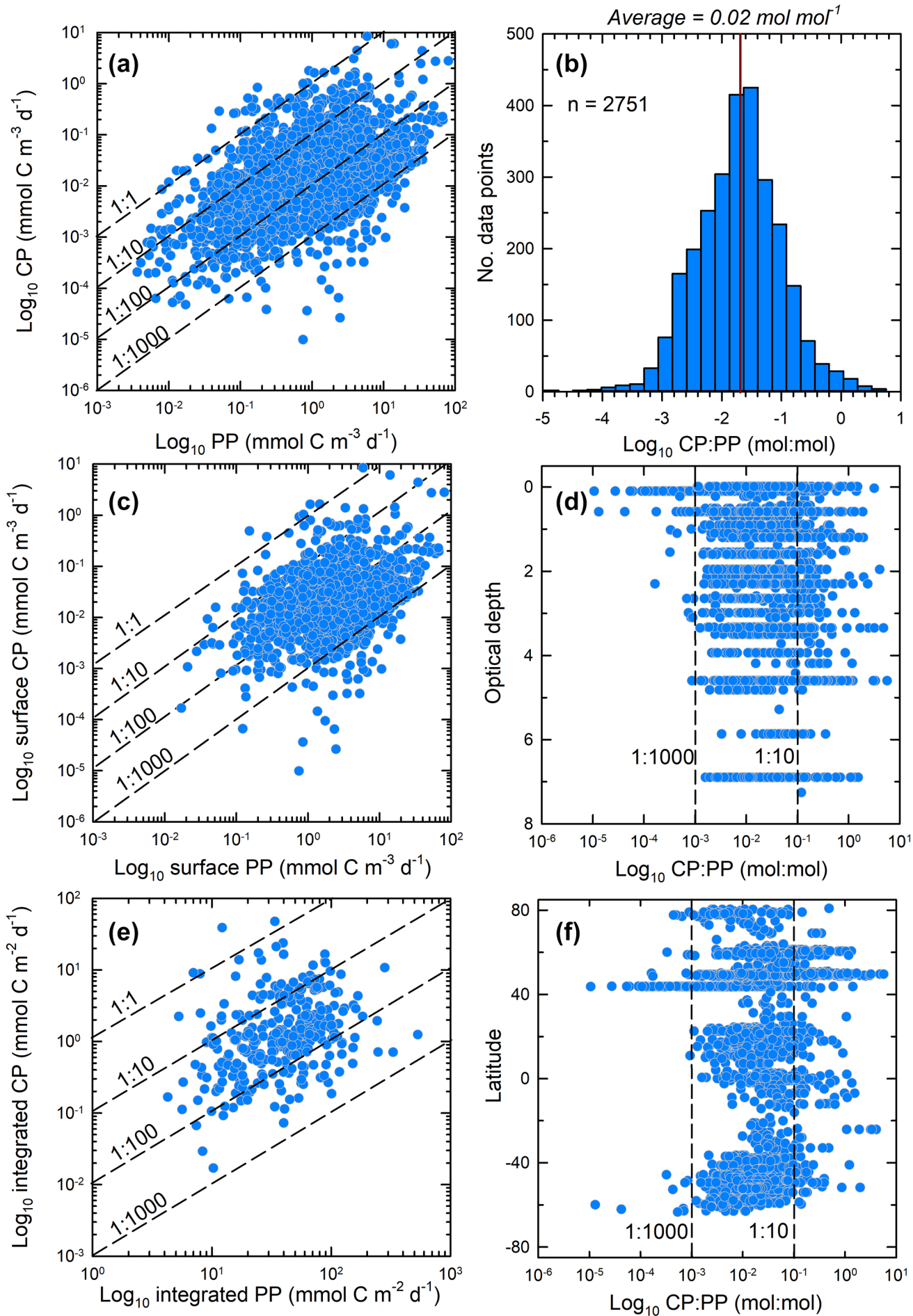

Figure 7. Characteristics of the relationship between $\mathrm{CaCO}_{3}$ production (CP) and primary production (PP): (a) scatterplot of all lognormalised CP and PP data, (b) frequency histogram of log-normalised CP to PP ratios for all data, (c) scatterplot of only surface $(<20 \mathrm{~m})$ $\log$-normalised CP and PP, (d) scatter plot of log-normalised CP : PP ratios against optical depth, (e) scatterplot of euphotic zone integrals of log-normalised CP and PP, and (f) scatter plot of log-normalised CP : PP ratios by latitude. Panels (a), (c), (d), (e) and (f) include dashed lines of constant CP : PP. Panel (b) has the geometric mean ratio of CP to PP for all data indicated. 


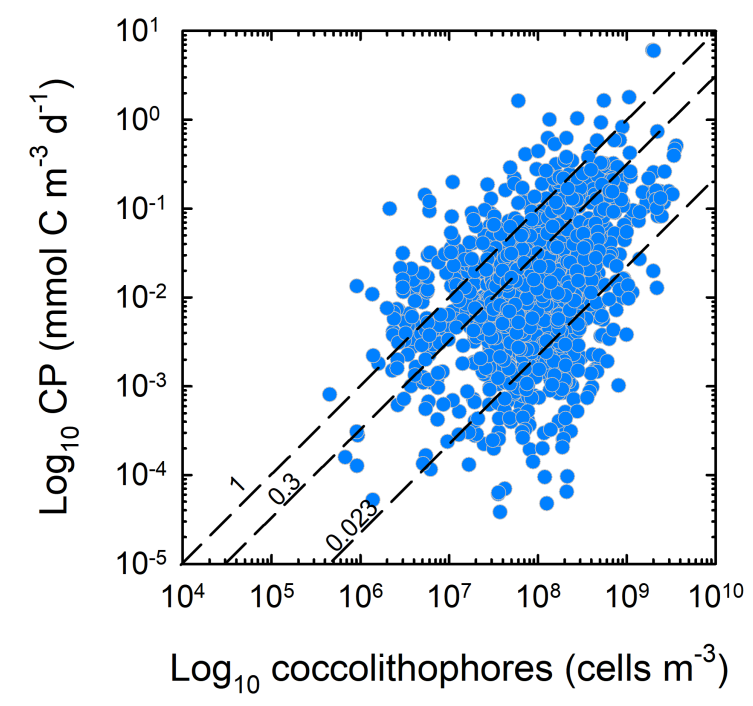

Figure 8. Scatterplot of log-normalised coccolithophore cell abundances and $\mathrm{CaCO}_{3}$ production $(\mathrm{CP})$ for all samples with matched count and rate data. Dashed lines indicate representative lines of cell-specific calcification (see Sect. 3.4).

\section{Conclusions and future recommendations}

We have assembled a database of 2765 data points of $\mathrm{CP}$ across the global ocean (from oceanic to coastal and tropical to polar), resulting in a significant increase in both the size and the spatial coverage of previous syntheses of similar measurements (Balch et al., 2007; Poulton et al., 2007). This database may be valuable in global-scale studies of CP and coccolithophores, though the main limitations of the current database are its spatial coverage, with particularly poor coverage in the Pacific, and a significant temporal bias towards spring-summer sampling.

The CP data are log-normally distributed, such that geometric means are required for examining the $\mathrm{CP}$ data. There is significant variability in the $\mathrm{CP}$ data, with no clear patterns in the global distribution of either surface or integrated $\mathrm{CP}$, although there is a strong relationship between surface $\mathrm{CP}$ and integrated $\mathrm{CP}$. We recommend that future field studies of CP use the MDT technique in combination with cell counts to obtain estimates of cell-CP to ground-truth the CP measurements. Cell-CP also provides further insights into the coccolithophore diversity and physiology underpinning measurements of CP. The MDT technique is the only direct method capable of accurately measuring low rates of $\mathrm{CP}$ (see Appendix A). The CP database is freely available and stored permanently from PANGAEA (Poulton et al., 2018; doi:10.1594/PANGAEA.888182) and there are plans to update it as and when new data become available. We hope that the database will be useful in model and satellite validation, as well as for examining spatial and temporal variability in $\mathrm{CP}$ on a global scale. 


\section{Appendix A}

In summer 2010, during a research cruise to the North Atlantic (RSS Discovery, 4 July to 11 August, D354) seawater samples were collected and analysed using both the difference technique (FF) and the micro-diffusion technique (MDT). Seawater for these comparisons was collected from sites $(n=19)$ in the Iceland and Irminger basins from subsurface $(\sim 5 \mathrm{~m})$ waters during predawn (06:00-07:00 local time) deployments of a titanium CTD (conductivity, temperature and depth) fitted with $10 \mathrm{~L}$ Niskin bottles on a rosette sampler.

For the MDT, $150 \mathrm{~mL}$ water samples (three light, one formalin killed) were spiked with 25 to $56 \mu \mathrm{Ci}(925-2072 \mathrm{kBq})$ of ${ }^{14} \mathrm{C}$-labelled sodium bicarbonate (PerkinElmer, UK) and incubated in on-deck incubators chilled with sea-surface seawater and with irradiance levels replicating $\sim 30 \%$ to $40 \%$ of surface incidental irradiance using misty blue light filters (Lee Filters ${ }^{\mathrm{TM}}$, UK). Incubations were terminated after $24 \mathrm{~h}$ by filtering through $25 \mathrm{~mm} 0.2 \mu \mathrm{m}$ polycarbonate filters, with extensive rinsing with fresh filtered seawater to remove any labelled ${ }^{14} \mathrm{C}$-DIC. Full methodology followed Poulton et al. $(2010,2013,2014)$ and gave measurements of primary production $\left(\mathrm{PP}_{\mathrm{MDT}}\right)$ and $\mathrm{CaCO}_{3}$ production $\left(\mathrm{CP}_{\mathrm{MDT}}\right)$. The average coefficient of variation of triplicate (light) $\mathrm{PP}_{\mathrm{MDT}}$ measurements was $14 \%$ (2\% to $66 \%)$ and $19 \%$ (1\% to $72 \%$ ) for $\mathrm{CP}_{\mathrm{MDT}}$, across a range of $\mathrm{PP} \mathrm{MDT}$ from 1.3 to $5.0 \mathrm{mmol} \mathrm{C} \mathrm{m}^{-3} \mathrm{~d}^{-1}$.

In parallel to the MDT measurements, measurements were also made of total particulate production and primary production $\left(\mathrm{PP}_{\mathrm{FF}}\right)$, with the difference between the two being taken as $\mathrm{CaCO}_{3}$ production (i.e. $\mathrm{CP}_{\mathrm{FF}}=\mathrm{TPP}-\mathrm{PP}_{\mathrm{FF}}$ ), following the general methodology of Fernandez et al. (1993) and Balch et al. (2000). Two slightly different protocols were used: for five experiments, TPP and $\mathrm{PP}_{\mathrm{FF}}$ were measured from separate bottles, while for fourteen experiments, TPP and $\mathrm{PP}_{\mathrm{FF}}$ were measured from the same bottle. Formalinkilled blanks were prepared in only seven experiments, with formalin values averaged and the average applied across the other twelve experiments. (Note that formalin-killed blank values were, on average, only $\sim 4 \%$ of TPP and $\mathrm{PP}_{\mathrm{FF}}$ values - range $2 \%$ to $6 \%$ for both).

Water samples $(150 \mathrm{~mL}, 3,6$ or 7 replicates) were collected, spiked with 3 to $13 \mu \mathrm{Ci}$ (108 to $489 \mathrm{kBq}$ ) of ${ }^{14} \mathrm{C}$ labelled sodium bicarbonate (PerkinElmer, UK) and incubated in parallel to the MDT samples. Incubations were terminated after $24 \mathrm{~h}$ with filtering through $25 \mathrm{~mm} 0.2 \mu \mathrm{m}$ polycarbonate filters, with extensive rinsing with fresh filtered seawater to remove any labelled ${ }^{14} \mathrm{C}$-DIC. Filters for the measurement of TPP were placed directly into scintillation cocktail after air-drying, while filters for $\mathrm{PP}_{\mathrm{FF}}$ were either acid fumed (hydrochloric acid, $2-3 \mathrm{~h}$ ) or had $1 \mathrm{~mL}$ of $1 \%$ phosphoric acid added (20-24 h). The average coefficient of variation of the triplicate TPP measurements was $13 \%(1 \%$ to $27 \%$ ) and $15 \%$ (4\% to $21 \%$ ) for $\mathrm{PP}_{\mathrm{FF}}$, across a range of
$\mathrm{PP}_{\mathrm{FF}}$ from 1.4 to $2.9 \mathrm{mmol} \mathrm{C} \mathrm{m}^{-3} \mathrm{~d}^{-1}$. (Note that the standard errors on the triplicate TPP measurements range from 95 to $1294 \mu \mathrm{mol} \mathrm{C} \mathrm{m}{ }^{-3} \mathrm{~d}^{-1}$, while the standard errors for $\mathrm{PP}_{\mathrm{FF}}$ range from 31 to $804 \mu \mathrm{mol} \mathrm{C} \mathrm{m}^{-3} \mathrm{~d}^{-1}$; these values are comparable to the higher end of $\mathrm{CP}$ measured in the open ocean, see main paper.)

Comparison of TPP and $\mathrm{PP}_{\mathrm{FF}}$ (Fig. A1) showed that the two are significantly positively correlated $(r=0.89, p<$ $0.001, n=15)$, though $\mathrm{PP}_{\mathrm{FF}}$ tended to be, on average, $\sim$ $27 \%$ (5\% to $54 \%$ ) lower than TPP. $\mathrm{PP}_{\mathrm{FF}}$ and $\mathrm{PP}_{\mathrm{MDT}}$ are also closely correlated (Fig. A1b; $r=0.71, p<0.005$ ) with the average difference being only $\sim 7 \%$ (although differences did span $-27 \%$ to $45 \%$ ). However, TPP being around a third higher than $\mathrm{PP}_{\mathrm{FF}}$ actually implies that rates of $\mathrm{CP}_{\mathrm{FF}}(=\mathrm{TPP}$ - $\mathrm{PP}_{\mathrm{FF}}$ ) range from 164 to $2081 \mu \mathrm{mol} \mathrm{C} \mathrm{m}^{-3} \mathrm{~d}^{-1}$ (Fig. A1c), with a cruise average of $952 \mu \mathrm{mol} \mathrm{C} \mathrm{m}{ }^{-3} \mathrm{~d}^{-1}$. In contrast, CPMDT only ranged from 4.1 to $141.8 \mu \mathrm{mol} \mathrm{C} \mathrm{m}^{-3} \mathrm{~d}^{-1}$ (with a cruise average of $68 \mu \mathrm{mol} \mathrm{C} \mathrm{m}{ }^{-3} \mathrm{~d}^{-1}$ ), which is $\sim 60$ to $\sim 9000$ times lower than $\mathrm{CP}_{\mathrm{FF}}$ (Fig. A1c), though the two are significantly correlated $(r=0.69, p<0.005, n=15)$. Since $\mathrm{PP}_{\mathrm{FF}}$ and $\mathrm{PP}_{\mathrm{MDT}}$ are strongly correlated, with a low relative difference between the two, the discrepancy between $\mathrm{CP}_{\mathrm{FF}}$ and $\mathrm{CP}_{\mathrm{MDT}}$ derives from the much higher measurement of TPP. At this time there are no clear explanations for why TPP is so high relative to PP. It may be speculated that it is linked to the treatment of the samples (air-drying), as both PP measures are exposed to acid, and hence an unidentified source of labelled carbon may be included in the TPP measurement but not those of PP. Further comment is outside the scope of this study.

Objectively determining which $\mathrm{CP}$ measurement is accurate is not straightforward. One way is to consider the cell-normalised rates of calcification (cell-CP); i.e. which set of CP gives physiologically realistic cell-CP? For example, based on culture and field data Emiliania huxleyi may have cell-CP of 0.1 to $1.0 \mathrm{pmol} \mathrm{C}$ cell d ${ }^{-1}$ (see discussion in Poulton et al., 2010, 2013, and references therein, as well as Daniels et al., 2014). Maximum cell-CP for heavier species such as Coccolithus pelagicus may reach as high as $\sim 8.3 \mathrm{pmol}_{\text {cell }}{ }^{-1} \mathrm{~d}^{-1}$ or $\sim 23.2 \mathrm{pmol} \mathrm{C}$ cell $^{-1} \mathrm{~d}^{-1}$ for $C$. braarudii (depending on cell calcite and growth rates; Daniels et al., 2014). For the 2010 North Atlantic data, calculated cell-CP $(n=12)$ for $\mathrm{CP}_{\mathrm{FF}}$ gives a range

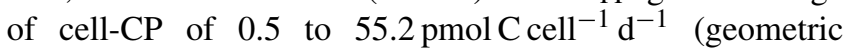

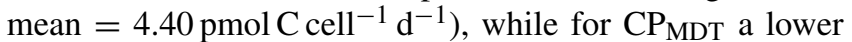
range of 0.02 to $3.36 \mathrm{pmolC}^{-1} \mathrm{cell}^{-1} \mathrm{~d}^{-1}$ (geometric mean $=0.25 \mathrm{pmol} \mathrm{Cell}^{-1} \mathrm{~d}^{-1}$ ) is calculated. Generally, cell-CP from $\mathrm{CP}_{\mathrm{FF}}$ is on average 32 times higher (full range 7-206) than cell-CP calculated from $\mathrm{CP}_{\text {MDT }}$. Cell-CP from the MDT gives values more in line with similar studies in the literature, although clearly further details of the species composition of the community (relative abundance, calcite content and growth rates) are required to fully reconcile the different estimates of cell-CF. 

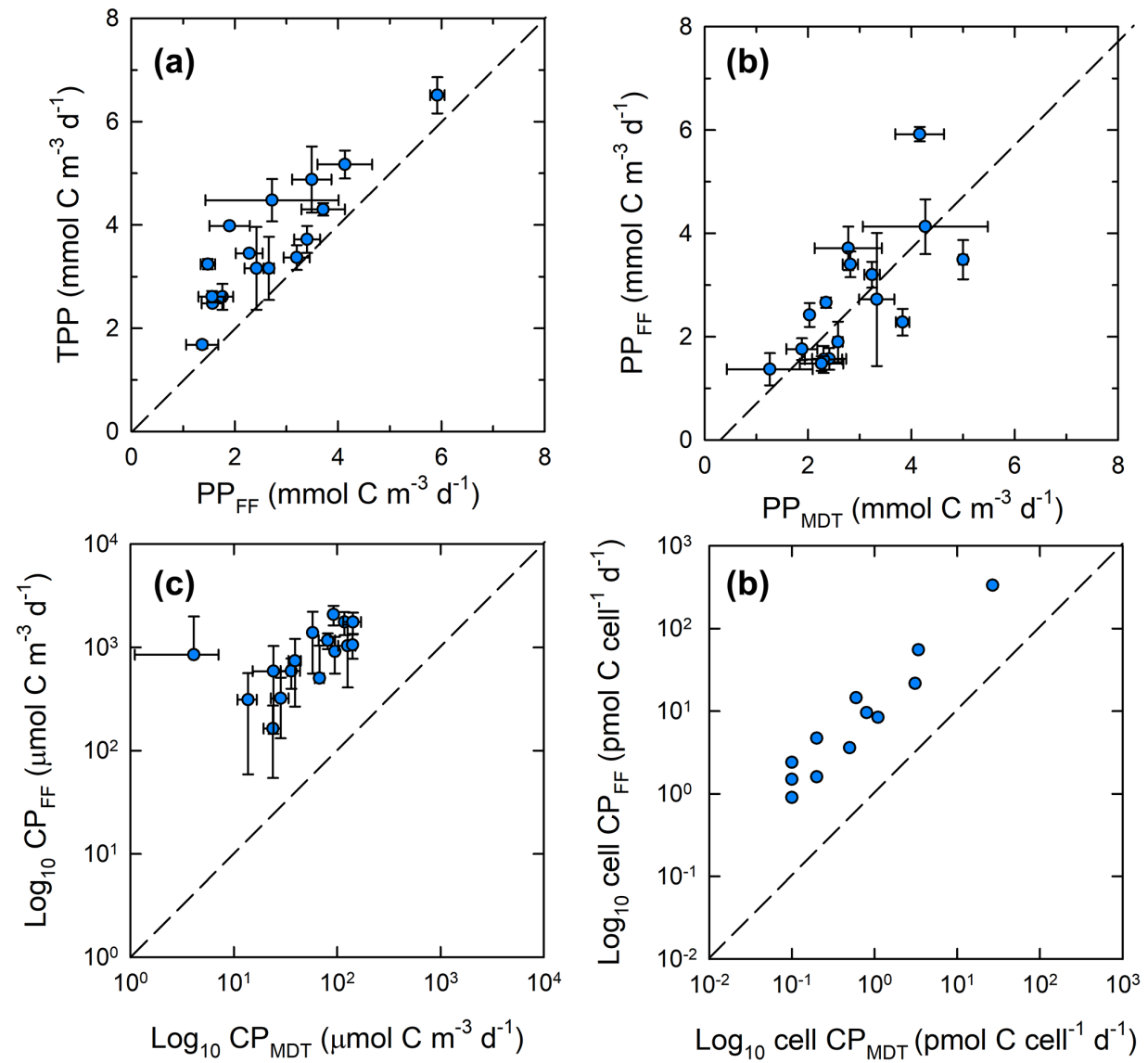

Figure A1. Scatterplots of (a) total particulate production (TPP) and primary production from the difference technique $(\mathrm{PP} F \mathrm{FF})$, (b) primary production from the micro-diffusion technique $\left(\mathrm{PP}_{\mathrm{MDT}}\right)$ and difference method $\left(\mathrm{PP}_{\mathrm{FF}}\right)$, (c) log-normalised $\mathrm{CaCO}_{3}$ production from the micro-diffusion technique (CP $\left(\mathrm{PDT}_{\mathrm{MD}}\right)$ and difference method $\left(\mathrm{CP}_{\mathrm{FF}}\right)$, and $(\mathbf{d})$ log-normalised cell-normalised rates (cell-CP) from the microdiffusion technique (cell-CPMDT) and difference method (cell-CP $\mathrm{FF}_{\mathrm{FF}}$. Dashed lines in all panels indicate unity.

To conclude, the MDT provided $\mathrm{CP}$ and cell-CP rates which are fully consistent with the database and wider literature, whereas the difference technique provides $\mathrm{CP}$ rates which are much higher than those most often found in nonbloom conditions in the North Atlantic and cell-CP rates which are high. Based on these observations, we suggest that the MDT should be used for further field studies and the difference technique should be reserved for culture-based studies. 
Author contributions. CJD and AJP devised the data synthesis and collated the data, with earlier assistance from RH. All authors contributed data to the database. WMB and EM commented on early drafts of the paper. All authors commented on subsequent drafts. KMJM and $\mathrm{JH}$ also assisted with the final versions of the figures.

Competing interests. The authors declare that they have no conflict of interest.

Acknowledgements. The authors wish to thank the research scientists, technicians, students and crew who contributed to the collection of these data. The authors also recognise funding from the UK Natural Environmental Research Council (NERC), the US National Science Foundation (NSF), the National Aeronautics and Space Administration (NASA), and the Spanish Ministry of Science and Innovation.

Edited by: David Carlson

Reviewed by: Lennart Bach and one anonymous referee

\section{References}

Archer, D. E.: An atlas of the distribution of calcium carbonate in sediments of the deepsea, Global Biogeochem. Cy., 10, 159-174, 1996.

Bach, L. T., Riebesell, U., Gutowska, M. A., Federwisch, L., and Schulz, K. G.: A unifying concept of coccolithophore sensitivity to changing carbonate chemistry embedded in an ecological framework, Prog. Oceanogr., 135, 125-138, https://doi.org/10.1016/j.pocean.2015.04.012, 2015.

Balch, W. M.: The ecology, biogeochemistry and optical properties of coccolithophores, Annu. Rev. Mar. Sci., 10, 71-78, 2018.

Balch, W. M. and Kilpatrick, K.: Calcification rates in the Equatorial Pacific along $140^{\circ} \mathrm{W}$, Deep-Sea Res. Pt. II, 43, 971-993, https://doi.org/10.1016/0967-0645(96)00032-X, 1996.

Balch, W. M., Holligan, P. M., and Kilpatrick, K. A.: Calcification, photosynthesis and growth of the bloom-forming coccolithophore, Emiliania huxleyi, Cont. Shelf Res., 12, 1353-1374, https://doi.org/10.1016/0278-4343(92)90059-s, 1992.

Balch, W. M., Kilpatrick, K., Holligan, P. M., Harbour, D., and Fernandez, E.: The 1991 coccolithophore bloom in the central North Atlantic: 2. Relating optics to coccolith concentration, Limnol. Oceanogr. 41, 1684-1696, 1996.

Balch, W. M., Drapeau, D. T., Cucci, T. L., Vaillancourt, R. D., Kilpatrick, K. A., and Fritz, J. J.: Optical backscattering by calcifying algae - Separating the contribution by particulate inorganic and organic carbon fractions, J. Geophys. Res., 104, 1541-1558, 1999.

Balch, W. M., Drapeau, D. T., and Fritz, J. J.: Monsoonal forcing of calcification in the Arabian Sea, Deep-Sea Res. Pt. II, 47, 13011337, https://doi.org/10.1016/S0967-0645(99)00145-9, 2000.

Balch, W. M., Drapeau, D. T., Bowler, B. C., Booth, E. S., Goes, J. I., Ashe, A., and Frye, J. M.: A multi-year record of hydrographic and bio-optical properties in the Gulf of Maine: I.
Spatial and temporal variability, Prog. Oceanogr., 63, 57-98, https://doi.org/10.106/j.pocean.2004.09.003, 2004.

Balch, W. M., Gordon, H. R., Bowler, C., Drapeau, D. T., and Booth, E. S.: Calcium carbonate measurements in the surface gloal ocean based on Moderate-Resolution Imaging Spectroradiometer data, J. Geophys. Res., 110, C07001, https://doi.org/10.1029/2004JC002560, 2005.

Balch, W. M., Drapeau, D., Bowler, B., and Booth, E.: Prediction of pelagic calcification rates using satellite measurements, Deep-Sea Res. Pt. II, 54, 478-495, https://doi.org/10.106/j.dsr2.2006.12.006, 2007.

Balch, W. M., Drapeau, D. T., Bowler, B. C., Booth, E. S., Windecker, L. A., and Ashe, A.: Space-time variability of carbon standing stocks and fixation rates in the Gulf of Maine, along the GNATS transect between Portland, ME, USA and Yarmouth, Nova Scotia, Canada, J. Plankton Res., 30, 119-139, https://doi.org/10.1093/plankt/fbm097, 2008.

Balch, W. M., Poulton, A. J., Drapeau, D., Bowler, B., Windecker, L., and Booth, E.: Zonal and meridional patterns of phytoplankton biomas and carbon fixation in the Equatorial Pacific Ocean, between $110^{\circ} \mathrm{W}$ and $140^{\circ} \mathrm{W}$, Deep-Sea Res. Pt. II., 58, 400-416, https://doi.org/10.1016/j.dsr2.2010.08.004, 2011.

Balch, W. M., Drapeau, D. T., Bowler, B. C., and Huntington, T. G.: Step-changes in the physical, chemical and biological characteristics of the Gulf of Maine, as documented by the GNATS time series, Mar. Ecol. Prog. Ser., 450, 11-35, https://doi.org/10.3354/meps09555, 2012.

Balch, W. M., Bowler, B. C., Lubelczyk, L. C., and Stevens Jr., M. W.: Aerial extent, composition, bio-optics and biogeochemistry of a massive under-ice algal bloom in the Arctic, Deep-Sea Res Pt. II, 105, 42-58, https://doi.org/10.1016/j.dsr2.2014.04.001, 2014.

Balch, W. M., Bates, N. R., Lam, P. J., Twining, B. S., Rosengard, S. Z., Bowler, B. C., Drapeau, D. T., Garley, R., Lubelczyk, L. C., Mitchell, C., and Rauschenberg, S.: Factors regulating the Great Calcite Belt in the Southern Ocean and its biogeochemical significance, Global Biogeochem. Cy., 30, 1124-1144, https://doi.org/10.1002/2016GB005414, 2016.

Balch, W. M., Bowler, B. C., Drapeau, D. T., Lubelczyk, L. C., and Lyczkowski, E.: Vertical distributions of coccolithophores, PIC, POC, biogenic Silica, and chlorophyll a throughout the global ocean, Global Biogeochem. Cy., 32, 1-16, https://doi.org/10.1002/2016GB005614, 2018.

Barber, R. T. and Hilting, A.: History of the study of plankton productivity, in: Phytoplankton productivity, carbon assimilation in marine and freshwater ecosystems, edited by: Williams, P. K. B., Thomas, D. N., and Reynolds, C. S., Blackwell Science, 16-43, 2002.

Behrenfeld, M. J. and Falkowski, P. G.: Photosynthetic rates derived from satellite-based chlorophyll concentration, Limnol. Oceanogr., 42, 1-20, 1997.

Berelson, W. M., Balch, W. M., Najjar, R., Feely, R. A., Sabine, C., and Lee, K.: Relating estimates of $\mathrm{CaCO}_{3}$ production, export, and dissolution in the water column to measurements of $\mathrm{CaCO}_{3}$ rain into sediment traps and dissolution on the sea floor: A revised global carbonate budget, Global Biogeochem. Cy., 21, GB1024, https://doi.org/10.1029/2006GB002803, 2007.

Boyd, P. W., Strzepek, R., Fu, F., and Hutchins, D. A.: Environmental control of open-ocean phytoplankton groups: 
Now and in the future, Limnol. Oceanogr., 55, 1353-1376, https://doi.org/10.4319/lo.2010.55.3.1353, 2010.

Burridge, A. K., Goetze, E., Wall-Palmer, D., Le Double, S. L., Huisman, J., and Peignenburg, K. T. C. A.: Diversity and abundance of pteropods and heteropods along a latitudinal gradient across the Atlantic Ocean, Prog. Oceanogr., 158, 213-233, 2017.

Charalampopoulou, A., Poulton, A. J., Tyrrell, T., and Lucas, M. I.: Irradiance and $\mathrm{pH}$ affect coccolithophore community composition on a transect between the North Sea and the Arctic Ocean, Mar. Ecol. Prog. Ser., 431, 25-43, https://doi.org/10.3354/meps09140, 2011.

Charalampopoulou, A., Poulton, A. J., Bakker, D. C. E., Lucas, M. I., Stinchcombe, M. C., and Tyrrell, T.: Environmental drivers of coccolithophore abundance and calcification across Drake Passage (Southern Ocean), Biogeosciences, 13, 59175935, https://doi.org/10.5194/bg-13-5917-2016, 2016.

Daniels, C. J., Sheward, R. M., and Poulton, A. J.: Biogeochemical implications of comparative growth rates of Emiliania huxleyi and Coccolithus species, Biogeosciences, 11, 6915-6925, https://doi.org/10.5194/bg-11-6915-2014, 2014.

Daniels, C. J., Poulton, A. J., Young, J. R., Esposito, M., Humphreys, M. P., Ribas-Ribas, M., Tynan, E., and Tyrrell, T.: Species-specific calcite production reveals Coccolithus pelagicus as the key calcifier in the Arctic Ocean, Mar. Ecol. Prog. Ser., 555, 29-47, https://doi.org/10.3354/meps11820, 2016.

Evans, D., Wade, B. S., Henehan, M., Erez, J., and Müller, W.: Revisiting carbonate chemistry controls on planktic foraminifera $\mathrm{Mg} / \mathrm{Ca}$ : implications for sea surface temperature and hydrology shifts over the Paleocene-Eocene Thermal Maximum and Eocene-Oligocene transition, Clim. Past, 12, 819-835, https://doi.org/10.5194/cp-12-819-2016, 2016.

Falkowski, P. G. and Raven, J. A.: Aquatic Photosynthesis, Princeton University Press, 1st Edn., 1997.

Feng, Y., Hare, C. E., Leblanc, K., Rose, J. M., Zhang, Y., DiTullio, G. R., Lee, P., Wilhelm, S., Rowe, J. M., and Sun, J.: The effects of increased $\mathrm{pCO}_{2}$ and temperature on the North Atlantic spring bloom: I. The phytoplankton communtiy and biogeochemical response, Mar. Ecol. Prog. Ser., 388, 13-25, https://doi.org/10.3354/meps08133, 2009.

Fernandez, E., Boyd, P., Holligan, P. M., and Harbour, D. S.: Production of organic and inorganic carbon within a large-scale coccolithophore bloom in the northeast Atlantic Ocean, Mar. Ecol. Prog. Ser., 97, 271-285, https://doi.org/10.3354/meps097271, 1993.

Fernandez, E., Marañón, E., Harbour, D. S., Kristiansen, S., and Heimdal, B.: Patterns of carbon and nitrogen uptake during blooms of Emiliania huxleyi in two Norwegian fjords, J. Plankton Res., 18, 2349-2366, 1996.

Field, C. B., Behrenfeld, M. J., Randerson, J. T., and Falkowski, P.: Primary production of the Biosphere: Integrating terrestrial and oceanic components, Science, 281, 237-240, https://doi.org/10.1126/science.281.5374.237, 1998.

Freeman, N. M. and Lovenduski, N. S.: Decreased calcification in the Southern Ocean over the satellite record, Geophys. Res. Lett., 42, 1834-1840, https://doi.org/10.102/2014GL062769, 2015.

Gehlen, M., Gangst $\varnothing$, R., Schneider, B., Bopp, L., Aumont, O., and Ethe, C.: The fate of pelagic $\mathrm{CaCO}_{3}$ production in a high $\mathrm{CO}_{2}$ ocean: a model study, Biogeosciences, 4, 505-519, https://doi.org/10.5194/bg-4-505-2007, 2007.
Henson, S. A., Sanders, R., and Madsen, E.: Global patterns in the efficiency of particulate organic carbon export and transport to the deep ocean, Global Biogeochem. Cy., 26, GB2023, https://doi.org/10.1029/2011GB004099, 2012.

Holligan, P. M., Charalampopoulou, A., and Hutson, R.: Seasonal distributions of the coccolithophore, Emiliania huxleyi, and of particulate inorganic carbon in surface waters of the Scotia Sea, J. Mar. Syst., 82, 195-205, 2010.

Hopkins, J. and Balch, W. M.: A new approach to estimating coccolithophore calcification rates from space, J. Geophys. Res., 123, GB1028, https://doi.org/10.1002/2017JG004235, 2018.

Hopkins, J., Henson, S. A., Painter, S. C., Tyrrell, T., and Poulton, A. J.: Phenological characteritics of global coccolithophore blooms, Global Biogeochem. Cy., 29, 239-253, https://doi.org/10.1002/2014GB004919, 2015.

Kirk, J. T. O.: Light and photosynthesis in aquatic ecosystems, Cambridge University Press, Cambridge, 1994.

Knap, A. H., Michaels, A., Close, A. R., Ducklow, H., and Dickson, A. G.: Protocols for the Joint Global Oean Flux Study (JGOFS) core measurements, JGOFS Report Nr. 19, IOC Manuals and Guides No. 29, UNESCO, 170, 1996.

Krumhardt, K. M., Lovenduski, N. S., Iglesias-Rodriguez, M. D., and Kleypas, J. A.: Coccolithophore growth and calcification in a changing ocean, Prog. Oceanogr., 159, 276-295, 2017.

Lam, P. J., Tortell, P. D., and Morell, F. M. M.: Differential effects of iron additions on organic and inorganic carbon production by phytoplanton, Limnol. Oceanogr., 46, 1199-1202, https://doi.org/10.4319/lo.2001.46.5.1199, 2001.

Landry, M. R., Selph, K. E., Taylor, A. G., Décima, M., Balch, W. M., and Bidigare, R. R.: Phytoplankton growth, grazing and production balances in the HNLC equatorial Pacific, Deep-Sea Res. Pt. II, 58, 524-535, 2011.

Limpert, E., Stahel, W. A., and Abbt, M.: Log-normal distribtuions across the sciences: Keys and Clues: On the charms of statistics, and how mechanical models resembling gambling machines offer a link to a handy way to characterize log-normal distributions, which can provide deeper insights into variability and probability - normal or log-normal: That is the question, Bioscience, 51, 341-352, https://doi.org/10.1641/00063568(2001)051[0341:LNDATS]2.0.CO;2, 2001.

Linschooten, C., van Bleijswijk, J. D. L., Van Emburg, P. R., de Vrind, J. P. M., Kempers, E. S., Westbroek, P., and de Vrind-de Jong, E. W.: Role of the light-dark cycle and medium composition on the production of coccoliths by Emiliania huxleyi (haptophyceae), J. Phycol., 27, 82-76, 1991.

Lipsen, M., Crawford, D., Gower, J., and Harrison, P.: Spatial and temporal variability in coccolithophore abundance and production of PIC and POC in the north-east subarctic Pacific during El Nino (1998), La Nina (1999) and 2000, Prog. Oceanogr., 75, 304-325, https://doi.org/10.1016/j.pocean.2007.08.004, 2007.

Mantyla, A. W., Venrick, E. L., and Hayward, T. L.: Primary production and chlorophyll relationships, derived from ten years of CalCOFl measurements, CalCOFl Rep., 36, 159-166, 1995.

Marañón, E. and Gonzalez, N.: Primary production, calcification and macromolecular synthesis in a bloom of the coccolithophore Emiliania huxleyi in the North Sea, Mar. Ecol. Prog. Ser., 157, 61-77, https://doi.org/10.3354/meps157061, 1997.

Marañón, E., Balch, W. M., Cermeño, P., González, N., Sobrino, C., Fernández, A., Huete-Ortega, M., López-Sandoval, D. C., Del- 
gado, M., Estrada, M., Álvarez, M., Fernández-Guallart, E., and Pelejero, C.: Coccolithophore calcification is independent of carbonate chemistry in the tropical ocean, Limnol. Oceanogr., 61, 1345-1357, https://doi.org/10.1002/lno.10295, 2016.

Marchetti, A., Sherry, N. D., Juneau, P., Strzepek, R. F., and Harrison, P. J.: Phytoplankon processes during a mesoscale iron enrichment in the northeast Pacific: Part III. Primary productivity, Deep-Sea Res. Pt. II, 53, 2131-2151, https://doi.org/10.1016/j.dsr2.2006.05.032, 2006.

Marra, J.: Approaches to the measurement of plankton production, in: Phytoplankton productivity: carbon assimilation in marine and freshwater ecosystems, edited by: Williams, P. K. le B., Thomas, D. N., and Reynolds, C. S., Blackwell Science, 78-108, 2002.

Mayers, K. M. J., Poulton, A. J., Daniels, C. J., Wells, S. R., Woodward, E. M. S., Tarran, G. A., Widdicombe, C. E., Mayor, D. J., Atkinson, A., and Giering, S. L. C.: Growth and mortality dynamics of coccolithophores during spring in a temperate Shelf Sea (Celtic Sea, April 2016), Prog. Oceanogr., https://doi.org/10.1016/j.pocean.2018.02.024, in press, 2018.

Meier, K. J. S., Young, J. R., Kirsch, M., and FeistBurkhardt, S.: Evolution of different life-cycle strategies in oceanic calcareous dinoflagellates, Eur. J. Phycol., 42, 81-89, https://doi.org/10.1080/09670260600937833, 2007.

Merz-Preiß, M.: Calcification in cyanobacteria, in: Microbial Sediments, edited by: Riding, R. E. and Awramik, S. M., Spring, Berlin, Heidelberg, 2000.

Milliman, J. D.: Production and accumulation of calcium carbonate in the ocean: Budget of a non-steady state, Global Bigeochem. Cy., 7, 927-957, 1993.

Monteiro, F. M., Bach, L. T., Brownlee, C., Brown, P., Rickaby, R. E. M., Poulton, A. J., Tyrrell, T., Beaufort, L., Dutkiewicz, S., Gibbs, S., Gutowska, M. A., Lee, R., Riebesell, U., Young, J. R., and Ridgwell, A.: Why marine phytoplankton calcify, Science Advances, 2, e1501822, https://doi.org/10.1126/sciadv.1501822, 2016.

Müller, M. N., Trull, T. W., and Hallegraeff, G. M.: Differing responses of three Southern Ocean Emiliania huxleyi ecotypes to changing seawater carbonate chemistry, Mar. Ecol. Prog. Ser., 531, 81-90, 2015.

O’Brien, C. J., Peloquin, J. A., Vogt, M., Heinle, M., Gruber, N., Ajani, P., Andruleit, H., Arístegui, J., Beaufort, L., Estrada, M., Karentz, D., Kopczynska, E., Lee, R., Poulton, A. J., Pritchard, T., and Widdicombe, C.: Global marine plankton functional type biomass distributions: coccolithophores, Earth Syst. Sci. Data, 5, 259-276, https://doi.org/10.5194/essd-5-259-2013, 2013.

O'Brien, C. J., Vogt, M., and Gruber, N.: Global coccolithophore diversity: Drivers and future chane, Prog. Oceanogr., 140, 2742, https://doi.org/10.1016/j.pocean.2015.10.003, 2016.

Paasche, E.: Coccolith formation, Nature, 193, 1094-1095, https://doi.org/10.1038/1931094b0, 1962.

Paasche, E.: The adaptation of the carbon-14 method for the measurement of coccolith production in Coccolithus huxleyi, Physiol. Plantarum, 16, 186-200, 1963.

Paasche, E.: Adjustment to light and dark rates of coccolith formation, Physiol. Plantarum, 19, 271-278, 1966.

Paasche, E.: A review of the coccolithophorid Emiliania huxleyi (Prymnesiophyceae), with particular reference to growth, coccol- ith formation, and calcification-photosynthesis interactions, Phycologia, 40, 503-529, 2002.

Paasche, E. and Brubak, S.: Enhanced calcification in the coccolithophorid Emiliania huxleyi (Haptophyceae) under phosphorus limitation, Phycologia, 33, 324-330, https://doi.org/10.2216/i0031-8884-33-5-324.1, 1994.

Poulton, A. J., Sanders, R., Holligan, P. M., Stinchcombe, M. C., Adey, T. R., Brown, L., and Chamberlain, K.: Phytoplankton mineralization in the tropical and subtropical Atlantic Ocean, Global Biogeochem. Cy., 20, GB4002, https://doi.org/10.1029/2006GB002712, 2006.

Poulton, A. J., Adey, T. R., Balch, W. M., and Holligan, P. M.: Relating coccolithophore calcification rates to phytoplankton community dynamics: Regional differences and implications for carbon export, Deep-Sea Res. Pt. II, 54, 538-557, https://doi.org/10.1016/j.dsr2.2006.12.003, 2007.

Poulton, A. J., Charalampopoulou, A., Young, J. R., Tarran, G. A., Lucas, M. I., and Quartly, G. D.: Coccolithophore dynamics in non-bloom conditions during late summer in the central Iceland Basin (July-August, 2007), Limnol. Oceanogr., 55, 1601-1613, https://doi.org/10.4319/lo.2010.55.4.1601, 2010.

Poulton, A. J., Young, J. R., Bates, N. R., and Balch, W. M.: Biometry of detached Emiliania huxleyi coccoliths along the Patagonian Shelf, Mar. Ecol. Prog. Ser., 443, 1-17, https://doi.org/10.3354/meps09445, 2011.

Poulton, A. J., Painter, S. C., Young, J. R., Bates, N. R., Bowler, B., Draeapeau, D., Lyczsckowski, E., and Balch, W. M.: The 2008 Emiliania huxleyi bloom along the Patagonian Shelf: Ecology, biogeochemistry, and cellular calcification, Global Biogeochem. Cy., 27, 1023-1033, https://doi.org/10.1002/2013GB004641, 2013.

Poulton, A. J., Stinchcombe, M. C., Achterberg, E. P., Bakker, D. C. E., Dumousseaud, C., Lawson, H. E., Lee, G. A., Richier, S., Suggett, D. J., and Young, J. R.: Coccolithophores on the north-west European shelf: calcification rates and environmental controls, Biogeosciences, 11, 3919-3940, https://doi.org/10.5194/bg-11-3919-2014, 2014.

Poulton, A. J., Holligan, P. M., Charalampopoulou, A., and Adey, T. R.: Coccolithophore ecology in the tropical and subtropical Atlantic Ocean: New perpectives from the Atlantic Meridional Transect (AMT) programme, Prog. Oceanogr., 158, 150-170, https://doi.org/10.1016/j.pocean.2017.01.003, 2017.

Poulton, A. J., Daniels, C. J., Balch, W. M., Marañón, E., Adey, T., Bowler, B. C., Cermeño, P., Charalampopoulou, A., Crawford, D. W., Drapeau, D. T., Feng, Y., Fernández, A., Fernández, E., Fragoso, G. M., González, N., Graziano, L. M., Heslop, R., Holligan, P. M., Hopkins, J., Huete-Ortega, M., Hutchins, D. A., Lam, P. J., Lipsen, M. S., López-Sandoval, D. C., Loucaides, S., Marchetti, A., Mayers, K. M. J., Rees, A. P., Sobrino, C., Tynan, E., and Tyrrell, T.: Global compilation of coccolithophore calcification measurements from unpeturbed water samples. PANNGAEA, https://doi.pangaea.de/ 10.1594/PANGAEA.888182, 2018.

Raven, J. A. and Crawfurd, K.: Environmental controls on coccolithophore calcification, Mar. Ecol. Prog. Ser., 470, 137-166, https://doi.org/10.3354/meps09993, 2012.

Rees, A. P., Woodward, E. M. S., Robinson, C., Cummings, D. G., Tarran, G. A., and Joint, I.: Size-fractionated nitrogen uptake and carbon fixation during a developing coccolithophore bloom in 
the North Sea during June, 1999, Deep-Sea Res. Pt. II, 49, 29052927, https://doi.org/10.1016/S0967-0645(02)00063-2, 2002.

Sarmiento, J. L., Dunne, J., Gnanadesikan, A., Key, R. M., Matsumoto, K., and Slater, R.: A new estimate of the $\mathrm{CaCO}_{3}$ to organic carbon export ratio, Global Biogeochem. Cy., 16, 1107, https://doi.org/10.1029/2002GB001919, 2002.

Schiebel, R.: Planktic foraminiferal sedimentation and the marine calcite budget, Global Biogeochem. Cy., 16, 1065, https://doi.org/10.1029/2001GB001459, 2002.

Schiebel, R. and Movellan, A.: First-order estimate of the planktic foraminifer biomass in the modern ocean, Earth Syst. Sci. Data, 4, 75-89, https://doi.org/10.5194/essd-4-75-2012, 2012.

Smith, V. S. and Mackenzie, F. T.: The role of $\mathrm{CaCO}_{3}$ reactions in the contemporary oceanic $\mathrm{CO}_{2}$ cycle, Aquat. Geochem., 22, 153-175, 2016.

Taylor, A. R., Brownlee, C., and Wheeler, G.: Coccolithophore cell biology: Chalking up progress, Annu. Rev. Mar. Sci., 9, 283-310, https://doi.org/10.1146/annurev-marine-122414-034032, 2016.

Van der Wal, P., Kempers, R. S., and Veldhuis, M. J. W.: Production and downward flux of organic matter and calcite in a North Sea bloom of the coccolithophore Emiliania huxleyi, Mar. Ecol. Prog. Ser., 126, 247-265, https://doi.org/10.3354/meps126247, 1995.
Yool, A., Popova, E. E., and Anderson, T. R.: MEDUSA-2.0: an intermediate complexity biogeochemical model of the marine carbon cycle for climate change and ocean acidification studies, Geosci. Model Dev., 6, 1767-1811, https://doi.org/10.5194/gmd6-1767-2013, 2013.

Young, J. R. and Ziveri, P.: Calculation of coccolith volume and its use in calibration of carbonate flux estimates, DeepSea Res. Pt. II, 47, 1679-1700, https://doi.org/10.1016/S09670645(00)00003-5, 2000.

Young, J. R., Davis, S. A., Bown, P. R., and Mann, S.: Coccolith ultrastructure and biomineralisation, J. Structural Biol., 126, 195215, 1999.

Young, J. R., Geisen, M., Cross, L., Kleijne, A., Sprengel, C., Probert, I., and Ostergaard, J.: A guide to extant coccolithophore taxonomy, J. Nannoplank. Res., 1, 1-132, 2003.

Zondervan, I.: The effects of light, macronutrients, trace metals and $\mathrm{CO}_{2}$ on the production of calcium carbonate and organic carbon in coccolthophores - A review, Deep-Sea Res. Pt. II, 54, 521537, 2007. 